\title{
Sex differences in the effect of cannabinoid type 1 receptor deletion on locus coeruleus-norepinephrine neurons and corticotropin releasing factor-mediated responses
}

\author{
DR. Ryan R. Wyrofsky ${ }^{1,}{ }^{,}$, Beverly A. S. Reyes ${ }^{1}$, Daohai Yu$^{2}$, Lynn G. Kirby ${ }^{3}$, and Elisabeth J. \\ Van Bockstaele ${ }^{1}$ \\ 1Department of Pharmacology and Physiology, College of Medicine, Drexel University, \\ Philadelphia, PA 19102 \\ 2Department of Clinical Sciences, Temple Clinical Research Institute, Lewis Katz School of \\ Medicine at Temple University, Philadelphia, PA 19140 \\ ${ }^{3}$ Center for Substance Abuse Research, Department of Anatomy and Cell Biology, Lewis Katz \\ School of Medicine at Temple University, Philadelphia, PA 19140
}

\begin{abstract}
Cannabinoids are capable of modulating mood, arousal, cognition, and behavior, in part via their effects on the noradrenergic nucleus locus coeruleus (LC). Dysregulation of LC signaling and norepinephrine (NE) efflux in the medial prefrontal cortex (mPFC) can lead to the development of psychiatric disorders, and $\mathrm{CB} 1 \mathrm{r}$ deletion results in alterations of a2- and $\beta 1$-adrenoceptors in the mPFC, suggestive of increased LC activity. To determine how CB1r deletion alters LC signaling, whole-cell patch-clamp electrophysiology was conducted in LC-NE neurons of male and female wild type (WT) and CB1r-knock out (KO) mice. CB1r deletion caused a significant increase in LC-NE excitability and input resistance in male but not female mice when compared to WT. CB1r deletion also caused adaptations in several indices of noradrenergic function. CB1r/CB2r-KO male mice had a significant increase in cortical NE levels and tyrosine hydroxylase and CRF levels in the LC compared to WT males. CB1r/CB2r-KO female mice showed a significant increase in LC a2-AR levels compared to WT females. To further probe actions of the endocannabinoid system as an anti-stress neuromediator, the effect of CB1r deletion on CRF-induced responses in the LC was investigated. The increase in LC-NE excitability observed in male and female WT mice following CRF (300 nM) bath application was not observed in CB1r-KO mice. These results indicate that cellular adaptations following CB1r deletion cause a disruption in LC-NE signaling in males but not females, suggesting underlying sex differences in compensatory mechanisms in $\mathrm{KO}$ mice as well as basal endocannabinoid regulation of LC-NE activity.
\end{abstract}

\footnotetext{
"Corresponding Author: Ryan Wyrofsky, Department of Pharmacology and Physiology, College of Medicine, Drexel University, 245 S. 15th Street, Philadelphia, PA 19102, Voice: (215) 762-2386, rrw47@ drexel.edu.

Author Contributions

RRW, LGK, and EJVB conceived and designed the study. RRW and BASR collected data. RRW and DY performed statistical analyses. RRW wrote the manuscript, with contributions from DY, LGK, and EJVB.

Conflict of Interest

The authors report no conflict of interest.

Data Accessibility

Data are available upon request from the corresponding author.
} 
Graphical Abstract
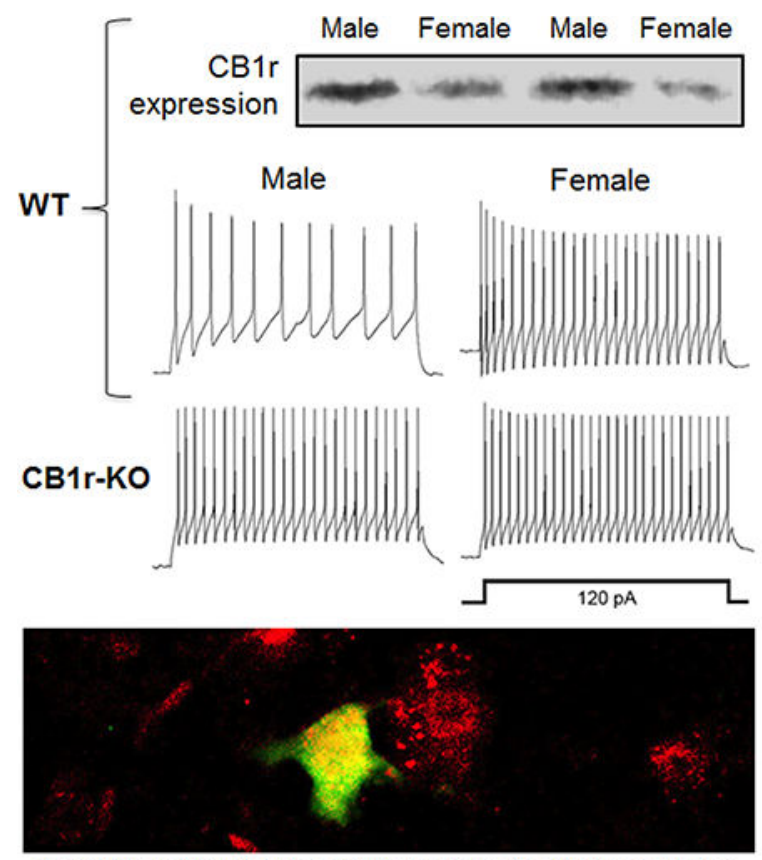

Recordings from locus coeruleus-norepinephrine neurons.

Novel electrophysiological data in mice reveals that cannabinoid receptor (CB1r) deletion results in a significant increase in locus coeruleus-norepinephrine (LC-NE) excitability in male mice, but not in females. Basal differences in CB1r expression were also observed, with male wild type (WT) having higher CB1r levels than female WT mice. Taken together, these data suggest that females may have less tonic endocannabinoid signaling in the LC-NE system compared to males, potentially contributing to the increased vulnerability of females to stress-induced psychiatric disorders.

\section{Keywords}

stress; sex differences; arousal; psychiatric disorders

\section{Introduction}

The brainstem nucleus locus coeruleus (LC) plays an important role in regulating mood, arousal, and emotional states (Aston-Jones and Cohen, 2005; Valentino and Van Bockstaele, 2008), and is the sole provider of norepinephrine (NE) to the medial prefrontal cortex (mPFC) (Sara, 2009). Dysregulation of the LC-NE system resulting in subsequent alterations in $\mathrm{mPFC}$ NE levels has been shown to precipitate the development of psychiatric disorders (Mueller et al., 2008; Mueller and Cahill, 2010). One of the most widely used recreational drugs in the world, cannabis, often causes feelings of relaxation and euphoria (Velez et al., 1989; Green et al., 2003; Di Marzo et al., 2004); however, chronic usage can be anxiogenic and produce dysphoria (Reilly et al., 1998). Via activation of cannabinoid type 1 receptors (CB1r), cannabinoids are known to affect attention and anxiety (Witkin et al., 2005; Pattij et al., 2008; Hill and Gorzalka, 2009), in part via actions on noradrenergic 
circuitry (Carvalho et al., 2010; Carvalho and Van Bockstaele, 2012; Wyrofsky et al., 2017). There are, however, some discrepancies within the cannabinoid field. While some studies find anxiolytic effects and therapeutic promise in cannabinoid treatments, others show that CB1r agonists can have a negative impact and promote anxiogenesis, and the exact dosage and experimental conditions can have a profound effect on whether targeting the endocannabinoid system could be beneficial (Di Marzo, 2008; Wyrofsky et al., 2015). Further investigation of how the eCB system targets neurotransmitter systems, like norepinephrine, can provide further insight into the differential effects of cannabinoid agonism.

Immunofluorescence and immunoelectron microscopy studies have provided direct anatomical evidence for $\mathrm{CB} 1 \mathrm{r}$ co-localization to noradrenergic terminals in the $\mathrm{mPFC}$ and localization to TH-containing neurons in the LC (Carvalho et al., 2010; Wyrofsky et al., 2017). Several studies have also shown that CB1r activation increases NE release. CB1r agonists WIN 55,212-2, tetrahydrocannabinol (THC), and CP 55940 dose-dependently increase the spontaneous firing rate of LC neurons (Mendiguren and Pineda, 2006; Muntoni et al., 2006). Both systemic and local administration of CB1r agonist WIN 55,212-2 increases c-Fos expression in LC-NE neurons and NE efflux in the rat mPFC (Oropeza et al., 2005; Page et al., 2008), as does inhibition of eCB catabolism with a fatty acid amide hydrolase (FAAH) inhibitor (Gobbi et al., 2005). Additionally, administration of the CB1r antagonist SR141716A causes a decrease in LC activity, suggesting that during basal conditions (Muntoni et al., 2006), the LC is under tonic eCB regulation (Carvalho and Van Bockstaele, 2012; Wyrofsky et al., 2015). Conversely, systemic administration of a CB1r antagonist rimonabant causes an increase in $\mathrm{mPFC}$ and hypothalamic NE levels (Tzavara et al., 2001; Tzavara et al., 2003), and low levels of THC can reduce NE release from synaptosomes (Poddar and Dewey, 1980). These anatomical and functional studies provide evidence that the eCB system can modulate the LC-NE system.

The eCB system is considered an "anti-stress" neuromediator (Viveros et al., 2007; Cota, 2008), playing a role in the hypothalamic pituitary adrenal (HPA) axis negative feedback loop as well as initiating the stress response in the amygdala (Hill and McEwen, 2009; Hill et al., 2010a; Hill et al., 2010b). The LC-NE system is involved in the cognitive limb of the stress response, and is activated in parallel with the HPA axis via corticotropin releasing factor (CRF), the pro-stress neuropeptide (Valentino and Van Bockstaele, 2008). Following a stressor, CRF is released from limbic and autonomic afferent sources such as the paraventricular nucleus of the hypothalamus, central nucleus of the amygdala, and bed nucleus of the stria terminalis (Van Bockstaele et al., 1996; Van Bockstaele et al., 1999; Van Bockstaele et al., 2001; Valentino and Van Bockstaele, 2008), and can lead to increases in LC-NE firing and dysregulation of NE release in target regions, including the mPFC (Curtis et al., 1996). We have recently shown that CB1r are positioned both pre- and postsynaptically with respect to CRF-containing afferents within the LC, providing a neural substrate for eCB modulation of CRF in this noradrenergic nucleus (Wyrofsky et al., 2017).

Research examining male CB1r-knockout (KO) mice show that $\mathrm{CB} 1 \mathrm{r}$ deletion increases anxiety and depressive-like behaviors in CB1r KO mice compared to wild type (WT) controls (Aso et al., 2008; Steiner et al., 2008; Parolaro et al., 2010; Wyrofsky et al., 2015). 
Additionally, CB1r-KO mice have increased plasma levels of adrenocorticotropin and corticosterone (Uriguen et al., 2004), and increased CRF mRNA expression in the hypothalamus, suggesting heightened HPA activity (Cota, 2008). We have also demonstrated that $\mathrm{CB} 1 \mathrm{r}-\mathrm{KO}$ mice have reduced basal $\mathrm{mPFC}$ neuronal excitability due to desensitization of the normally excitatory mPFC a2-adrenoceptors (ARs) (Reyes et al., 2017). These KO studies suggest that CB1r-KO mice have increased LC-NE release, which desensitized mPFC a2-ARs, resulting in decreased mPFC output (Reyes et al., 2017).

In the present study, we used two strains of cannabinoid receptor KO mice to define electrophysiological properties of LC-NE neurons as well as effects on CRF-mediated responses, and cellular adaptions that occur in absence of the cannabinoid receptors: CB1r$\mathrm{KO}$ mice for in vitro slice electrophysiology studies and dual CB1r/CB2r-KO mice for Western and ELISA experiments. First, whole-cell patch clamp electrophysiological recordings were conducted in WT and CB1r-KO mice to measure basal properties of LC-NE neurons and their excitability. Next, we used Western blot analysis to measure expression levels of the catecholamine synthesizing enzyme tyrosine hydroxylase (TH) in the LC and assessed cortical NE levels via ELISA in CB1r/CB2r-KO mice. We also investigated expression levels of CRF, a2-AR, NET, and CB1r in the coeruleo-cortical pathway. Finally, the effect of CRF administration on LC-NE activity in CB1r-KO mice was assessed using whole-cell patch-clamp recordings. Considering previous reports showing female rodents are more sensitive to the reinforcing effects of cannabinoids and are more likely to selfadminister WIN 55,212-2 than males (Barna et al., 2004; Fattore et al., 2007; Roberts et al., 2014) and sex differences in CRF signaling within the LC, with female rodents having increased sensitivity to CRF following a stressor compared to males (Bangasser et al., 2010; Valentino et al., 2013), we included both male and female mice in the study. These experiments help address the current gap in our understanding of how CB1r-KO differentially affects the LC-NE and stress systems across sexes.

\section{Methods}

\section{Animals}

For electrophysiology studies, male and female wild-type (WT) and CB1r KO mice (9-12 weeks old) were housed four per cage in a controlled environment (12-hour light schedule, temperature at $20^{\circ} \mathrm{C}$ ). Electrophysiology data for input resistance and excitability was obtained from $\mathrm{N}=5 \mathrm{LC}$ cells from $5 \mathrm{WT}$ male mice, $\mathrm{N}=4$ cells from 4 WT female mice, $\mathrm{N}=6$ cells from $5 \mathrm{KO}$ male mice, and $\mathrm{N}=7$ cells from $4 \mathrm{KO}$ female mice. Electrophysiology data for membrane characteristics was obtained from $\mathrm{N}=4$ cells from 4 WT male mice, $\mathrm{N}=4$ cells from 4 WT female mice, $\mathrm{N}=5$ cells from $\mathrm{KO}$ male mice, and $\mathrm{N}=4$ cells from $\mathrm{KO}$ female mice. For Western blot and ELISA analysis, male and female WT and CB1r/CB2r dual KO mice (9-18 weeks old) were used. For LC Western blot analysis of CRF, a 2-AR, and NET, data represents $\mathrm{N}=3 \mathrm{WT}$ male mice, $\mathrm{N}=6 \mathrm{KO}$ male mice, $\mathrm{N}=3 \mathrm{WT}$ female mice, and $\mathrm{N}=6$ $\mathrm{KO}$ female mice. For LC Western blot analysis of CB1r, data represents $\mathrm{N}=7$ WT male mice and $\mathrm{N}=5 \mathrm{WT}$ female mice. For mPFC Western blot and ELISA analyses, data represents $\mathrm{N}=3 \mathrm{WT}$ male mice, $\mathrm{N}=5 \mathrm{KO}$ male mice, $\mathrm{N}=3 \mathrm{WT}$ female mice, and $\mathrm{N}=4 \mathrm{KO}$ female mice. 
Both CB1r and CB1r/CB2r KO mice were originally generated on a C57B1/6 background by Zimmer et al. (Zimmer et al., 1999) at the National Institutes of Health. Heterozygous breeding pairs were generously donated by Dr. Carl Lupica at the National Institutes of Health and were bred and genotyped at Temple University to obtain CB1r and CB1r/CB2r KO mice and WT littermates. All WT mice used in comparison with CB1r or CB1r/CB2r $\mathrm{KO}$ mice were littermates and shared a common genetic background. Food and water were provided ad libitum.

The care and use of animals were approved by the Institutional Animal Care and Use Committee of both Drexel University and Temple University, and were conducted in accordance with the National Institutes of Health's Guide for the Care and Use of Laboratory Animals (1996), the Health Research Extension Act (1985), and the PHS Policy on Humane Care and Use of Laboratory Animals (1986). All efforts were made to utilize only the minimum number of animals necessary to produce reliable scientific data, and experiments were designed to minimize any animal distress.

\section{Drug preparation and administration}

Ovine CRF, generously provided by Dr. Jean Rivier (Clayton Foundation Laboratories for Peptide Biology, The Salk Institute, La Jolla, CA), was dissolved in water to make a 1 $\mathrm{mg} / \mathrm{mL}$ solution and separated into $10 \mu \mathrm{L}$ aliquots, which were concentrated using a Savant Speed Vac concentrator. Aliquots were stored at $-80^{\circ} \mathrm{C}$ until the day of the experiment, when they were then reconstituted in aCSF and added to the perfusion bath at a final concentration of $300 \mathrm{nM}$ CRF. $300 \mathrm{nM} \mathrm{CRF}$ was established as the optimal concentration based on a concentration-response curve (100-400 nM) tested in brain slices from male WT mice (data not shown). Additionally, this dose matches with previous sources confirming that $300 \mathrm{nM}$ CRF produces maximal increases in LC-NE excitability (Jedema and Grace, 2004).

\section{Electrophysiology}

All electrophysiology procedures were conducted as described previously (Reyes et al., 2012; Cathel et al., 2014). Male and female CB1r KO and WT mice were rapidly decapitated and brains rapidly extracted and placed in ice-cold artificial cerebrospinal fluid (aCSF), in which sucrose $(248 \mathrm{mM})$ was substituted for $\mathrm{NaCl}$. The brains were trimmed down to isolate the brainstem, and $250 \mu \mathrm{m}$ horizontal slices containing the $\mathrm{LC}$ were cut on a Vibratome 3000 Plus (Vibratome, St. Louis, MO, USA). Slices were then incubated for $1 \mathrm{~h}$ in aCSF at $35^{\circ} \mathrm{C}$, and bubbled with $95 \% \mathrm{O}_{2} / 5 \% \mathrm{CO}_{2}$. Slices were then maintained at aCSF at room temperature and bubbled with $95 \% \mathrm{O}_{2} / 5 \% \mathrm{CO}_{2}$. The aCSF was composed of the following: $124 \mathrm{mM} \mathrm{NaCl}, 2.5 \mathrm{mM} \mathrm{KCl}, 2 \mathrm{mM} \mathrm{NaH} \mathrm{PO}_{4}, 2.5 \mathrm{mM} \mathrm{CaCl}_{2}, 2 \mathrm{mM} \mathrm{MgSO}_{4}, 10$ $\mathrm{mM}$ dextrose, and $26 \mathrm{mM} \mathrm{NaHCO}_{3}$.

Slices were transferred to a recording chamber (Warner Instruments, Hamden, CT, USA) and continuously perfused with aCSF at a rate of $1.5-2.0 \mathrm{~mL} / \mathrm{min}$ at a temperature of $34^{\circ} \mathrm{C}$, maintained by an inline solution heater (TC-324; Warner Instruments, Hamden, CT, USA). Data were obtained from one to two neurons per mouse; however, only one neuron was recorded per brain slice. Neurons in the LC were visualized using a Nikon E600 upright 
microscope fitted with a 40x water immersion objective, differential interference contrast and infrared filter (Optical Apparatus, Ardmore, PA, USA). The microscope was connected to a CCD camera and computer monitor. LC-NE cells were tentatively identified by their morphology and electrophysiological characteristics (Williams et al., 1984), using the fourth ventricle as a marker for the location of the $\mathrm{LC}$ nucleus. Whole-cell recording pipettes were made with borosilicate glass capillary tubing $(1.2 \mathrm{~mm}$ outer diameter, $0.69 \mathrm{~mm}$ inner diameter; Warner Instruments) on a P-97 micropipette puller (Sutter Instruments, Novato, CA, USA). Electrodes were pulled to a resistance of 4-8 $\mathrm{M} \Omega$ when filled with an intracellular solution containing $120 \mathrm{mM} \mathrm{K}$-gluconate, $10 \mathrm{mM} \mathrm{KCl}, 1 \mathrm{mM} \mathrm{MgCl}_{2}, 10 \mathrm{mM}$ EGTA, $10 \mathrm{mM}$ HEPES, $2 \mathrm{mM}$ MgATP, $0.5 \mathrm{mM} \mathrm{Na} 2 \mathrm{GTP}, 10 \mathrm{mM}$ Na phosphocreatinine, and $0.1 \%$ biocytin, $\mathrm{pH}$ 7.3. Cells were approached with the electrode until a $\mathrm{G} \Omega$ seal was established, and the cell membrane ruptured to obtain a whole-cell recording using HEKA patch-clamp EPC-10 amplifier (HEKA Elecktronik, Pfalz, Germany) under current clamp conditions $(\mathrm{I}=0 \mathrm{pA})$. The series resistance was monitored throughout the experiment, and if it appeared unstable or exceeded four times the electrode resistance, the cell was discarded. Signals were stored on-line using Pulse software, filtered at $1 \mathrm{kHz}$ and digitized at $10 \mathrm{kHz}$. The liquid junction potential was approximately $9 \mathrm{mV}$ between the pipette solution and the aCSF, and was not subtracted from the data obtained.

At baseline, membrane potential was recorded and input resistance calculated by averaging the voltage change that occurred during a 300pA current pulse and using the current/voltage relationship. Neuronal excitability was assessed in each cell by injecting a series of current pulses ( $0-180 \mathrm{pA}, 30 \mathrm{pA}$ increments), and the number of action potential per pulse was determined. Additionally membrane characteristics were recorded, including action potential (AP) amplitude, AP duration, AP threshold, afterhyperpolarization potential (AHP) duration, and AHP amplitude. After baseline recordings were performed, $300 \mathrm{nM} \mathrm{CRF}$ was bath applied, and membrane potential, input resistance, neuronal excitability, and membrane characteristics were re-assessed 6 minutes after drug application.

Following electrophysiological experiments, dual fluorescence immunohistochemistry techniques were used to confirm that recordings were performed in LC-NE cells. Slices that were used for recordings were post-fixed in $4 \%$ formaldehyde solution on $0.1 \mathrm{M}$ phosphate buffer (PB; pH 7.4) for 72 hours. Biocytin-filled (recorded) neurons were visualized using an Alexa Fluor 488-conjugated streptavidin antibody (1:500, ThermoFisher Scientific, Waltham, MA, USA). Tyrosine hydroxylase (TH) was visualized using a primary TH antibody raised in mouse (1:1000, $48 \mathrm{~h}$ incubation, Immunostar, Hudson, WI) followed by Alexa Fluor 647-conjugated mouse secondary antibody (1:400, Jackson ImmunoResearch, West Grove, PA, USA). Images were examined using an Olympus IX81 inverted microscope (Olympus, Hatagaya, Shibuya-Ku, Tokyo, Japan) equipped with lasers (Helium Neon laser and Argon laser; models GLG 7000; GLS 5414A and GLG 3135, Showa Optronics Co., Tokyo, Japan) with the excitation wavelength of 488,543 , and 635 . Data from recorded cells that were not co-stained with TH were excluded. 


\section{Data analysis for electrophysiology}

Electrophysiological recordings were analyzed using Clampfit 9.2 (Axon Instruments, Foster City, CA, USA). The effect of genotype on input resistance and membrane characteristics across males and females was tested using two-way ANOVA (sex*genotype) followed by post-hoc Tukey's multiple comparison adjustments. The effect of CRF on input resistance and membrane characteristics across genotypes of males and females was tested using two-way ANOVA (sex*genotype) followed by post-hoc Tukey's multiple comparison adjustments. These statistics were performed using GraphPad Prism 7.03 (GraphPad Software, San Diego, CA, USA). The effect of sex and genotype on neuronal excitability was tested using a three-way repeated measure ANOVA/mixed-effects regression model (with sex, genotype, and injected current as covariates, along with a random effect for repeated measures from injected current), while the effect of CRF on neuronal excitability was tested by using a second mixed-effects regression model (with sex, genotype, injected current, and drug treatment as covariates, along with a random effect for repeated measures from injected current and drug treatment), both followed by post-hoc Tukey's multiple comparison adjustments when appropriate. Statistical analyses for neuronal excitability were performed using SAS version 9.4 (SAS Institute Inc., Cary, NC). Results are presented as mean $+/-$ SEM, based off of the number of cells per group. P-values less than 0.05 were considered statistically significant.

\section{Protein extraction}

Brain tissue from male and female WT and $\mathrm{CB} 1 \mathrm{r} / \mathrm{CB} 2 \mathrm{r}$ KO mice was rapidly removed from each animal on ice. Using a trephine, the LC and $\mathrm{mPFC}$ brain regions were microdissected from each animal. Tissue punches were homogenized with a pestle, sonicated, and extracted in radioimmunoprecipitation assay lysis buffer with a protease inhibitor cocktail (Santa Cruz Biotechnology, Santa Cruz, CA, USA) on ice for $20 \mathrm{~min}$. Lysates were cleared by centrifugation at $13,000 \mathrm{rpm}$ for $12 \mathrm{~min}$ at $4^{\circ} \mathrm{C}$, and supernatants were extracted. Protein concentrations were quantified using the bicinchoninic acid protein assay reagent (Pierce, Rockford, IL, USA).

\section{Western blot analysis}

Protein extracts were diluted with an equal volume of Novex 2@ tris glycine sodium dodecyl sulfate sample buffer (Invitrogen, Carlsbad, CA, USA) containing dithiothreitol (SigmaAldrich Inc., St. Louis, MO, USA). Cell lysates containing equal amounts of protein (30 $\mu \mathrm{g}$ per condition) were separated on $10 \%$ tris-glysine polyacrylamide gels and then electrophoretically transferred to Immobilon-P polyvinylidene fluoride membranes (Millipore, Bedford, MA, USA). Membranes were blocked with Odyssey buffer (1 h, diluted in $0.01 \mathrm{M}$ PBS 1:1) and incubated in the various combinations of the following primary antibodies overnight at room temperature (Table I): mouse anti-tyrosine hydroxylase (TH; 1:1000, Immunostar Inc., Hudson, WI), rabbit anti-a2-adrenoceptor (a2-AR; 1:500; Millipore Sigma, Billerica, MA, USA), guinea-pig anti-CRF (1:2000, Peninsula Laboratories, San Carlos, CA, USA), mouse anti-norepinephrine transporter (NET; 1:1000, Millipore Sigma, Billerica, MA, USA), guinea-pig anti-CB1r (1:500; gift from Dr. Mackie). Mouse anti-glyceraldehyde 3-phosphate dehydrogenase (GAPDH; 1:2000, ProteinTech 
Group, Inc., Rosemont, IL, USA) was used as a loading control, to account for potential variability in amount of sample loaded. Membranes were then rinsed and incubated with infrared fluorescent secondary antibodies (Licor, Lincoln, NE, USA) for $1 \mathrm{~h}$ : donkey antirabbit IRDye 800CW $(1: 15,000)$, donkey anti-guinea-pig IRDye800 CW (1:15000), goat anti-mouse IRDye680LT (1:20,000). Membranes were scanned using the Odyssey Infrared Imaging System (Licor, Lincoln, NE, USA), and protein quantification was determined using Odyssey Infrared Imaging software. Protein quantification was normalized to the loading control, and all data is presented as a ratio of sample protein level to GAPDH level, to allow for comparison between groups.

Additionally, Chameleon Duo Pre-stained Protein Ladder (Licor, Lincoln, NE, USA) was used to determine the molecular weights of protein bands observed: GAPDH $-\sim 37 \mathrm{kDa}$, $\mathrm{CRF}-\sim 25 \mathrm{kDa}$, a2-AR - $45 \mathrm{kDa}, \mathrm{TH}-\sim 60 \mathrm{kDa}$, NET $-\sim 80 \mathrm{kDa}, \mathrm{CB} 1 \mathrm{r}-\sim 53 \mathrm{kDa}$. Only proteins that did not fall around the same molecular weight were probed for at the same time. After imaging, membranes were stripped with NewBlot PVDF 5x Stripping Buffer (Licor, Lincold, NE, USA) mixed with four parts $\mathrm{DiH}_{2} \mathrm{O}$ for $20 \mathrm{~min}$ at room temperature. Blots were then rinsed and imaged to ensure removal of antibodies. Then, the blot could be incubated again with other primary antibodies to detect additional proteins.

\section{ELISA}

Sandwich ELISA was conducted in accordance with the instructions provided in the High Sensitivity NE Kit (Eagle, Nashau, NH). Tissue lysates containing equal amounts of protein were dispensed into an extraction plate and incubated for $60 \mathrm{~min}$ in $100 \mu \mathrm{l}$ extraction buffer at room temperature on an orbital shaker. The solution was then discarded and the extraction plates were washed before $200 \mu \mathrm{l}$ acylation buffer was dispensed into each well of the extraction plate and left rotating at room temperature for $20 \mathrm{~min}$. Liquid was then decanted and washed 3 times prior to the dispense of $125 \mu \mathrm{l} 0.025 \mathrm{M}$ hydrochloric acid into each well for an additional $20 \mathrm{~min}$ for elution. Next, $100 \mu \mathrm{l}$ eluent was transferred to the enzyme plate with $20 \mu \mathrm{l}$ of freshly prepared enzyme mix ( $2 \mathrm{ml}$ Catechol-O-methyltransferase with $0.3 \mathrm{ml}$ S-adenosyl-L-methionine in $0.7 \mathrm{ml}$ enzyme buffer) into all wells of the enzyme plate and left at room temperature for $90 \mathrm{~min}$. Finally, $100 \mu \mathrm{l}$ of the supernatant of each well was transferred to the NE ELISA with $20 \mu \mathrm{l}$ of rabbit NE-antiserum and left overnight at $4^{\circ} \mathrm{C}$. The following day all wells were decanted and washed 3 times before incubation with $100 \mu \mathrm{l}$ anti-rabbit IgG-POD-conjugate for $60 \mathrm{~min}$ at room temperature on an orbital shaker. The wells were subsequently washed 4 times and incubated with $100 \mu \mathrm{l}$ of TMB solution for 40 min before $100 \mu \mathrm{l}$ of stop solution was dispensed into the wells and the plate was read at 450 $\mathrm{nm}$ within $15 \mathrm{~min}$. A standard curve was run for each replicate and was used to estimate the concentration of NE in each sample.

\section{Data analysis for Western blot and ELISA}

Differences in CRF, a2-AR, NET, TH, and NE levels were tested using two-way ANOVA/ mixed-effects regression model (sex*genotype) followed by post-hoc Tukey's multiple comparison adjustments. Differences in CB1r expression across sexes were tested using a two-sample t-test. Statistics for the Western blot and ELISA experiments were performed using GraphPad Prism 7.03 (GraphPad Software, San Diego, CA, USA). Results are 
presented as mean +/- SEM. P-values less than 0.05 were considered statistically significant.

\section{Results}

\section{Heightened LC-NE activity in male CB1r-KO mice}

As previously stated, exogenous cannabinoids are known to increase LC-NE activity (Patel and Hillard, 2003; Muntoni et al., 2006). Conversely, others studies have shown that the LC is under tonic eCB regulation and male $\mathrm{CB} 1 \mathrm{r}-\mathrm{KO}$ mice have decreased a2- and $\beta 1$ adrenoceptor levels in the $\mathrm{mPFC}$, suggestive of compensatory responses to heightened LCNE activity (Reyes et al., 2017). In order to elucidate the effect of CB1r-KO on LC-NE signaling across sexes, whole-cell patch-clamp recordings from LC-NE neurons in 250um thick horizontal brain slices from CB1r-knock out (KO) mice and their wild type (WT) C57/B16 mice littermates were analyzed (Fig. 1). There was a significant effect of sex on input resistance $\left(\mathrm{F}_{1,17}=4.485, \mathrm{p}=0.049\right)$ and genotype on input resistance $\left(\mathrm{F}_{1,17}=13.24\right.$, $\mathrm{p}=0.002$ ), but no significant effect of interaction between sex and genotype on input resistance $\left(\mathrm{F}_{1,17}=2.972, \mathrm{p}=0.10\right)$. Tukey's post-hoc analysis revealed that male $\mathrm{CB} 1 \mathrm{r}-\mathrm{KO}$ mice showed a significant increase in input resistance $(376 \pm 31 \mathrm{M} \Omega$ ) when compared to male WT mice ( $224 \pm 13 \mathrm{M} \Omega$; $\mathrm{p}=0.006)$, female WT mice ( $213 \pm 39 \mathrm{M} \Omega ; \mathrm{p}=0.005)$, and female $\mathrm{KO}$ mice ( $267 \pm 25 \mathrm{M} \Omega$; $\mathrm{p}=0.041$ ), while there was no significant change in input resistance between female WT and KO mice ( $\mathrm{p}=0.57$ ) (Fig. 1B). A three-way repeated measures ANOVA/mixed effects regression model (genotype effect by sex*current pulse (repeated measure); sex effect by genotype*current pulse (repeated measure)) showed a significant effect of the following in the collected electrophysiology data: genotype $\left(\mathrm{F}_{1,18}=11.41, \mathrm{p}=0.003\right)$, current pulse $\left(\mathrm{F}_{6,104}=75.78, \mathrm{p}<0.0001\right)$, interaction between sex and genotype $\left(\mathrm{F}_{1,18}=7.23, \mathrm{p}=0.015\right)$, interaction sex $*$ genotype*current pulse $\left(\mathrm{F}_{5,104}=2.72\right.$, $\mathrm{p}=0.024$ ), indicating all three factors were statistically significant in the regression model. Baseline membrane voltage was not significantly different between CB1r KO and WT for male and female mice. Further statistical examination of the data via Tukey post-hoc analysis revealed that genotype had a significant effect across all current pulses in male mice ( $\mathrm{p} \unlhd$ (0.016), but not females ( $\mathrm{p} \searrow 0.24$ ). Male CB1r-KO mice exhibited an increase in LC-NE cell excitability compared to male WT mice [leftward shift of the stimulus-response curve; significantly increased excitability responses to $30(\mathrm{p}=0.016), 60(\mathrm{p}=0.0005), 90(\mathrm{p}=0.0001)$, 120 ( $\mathrm{p}<0.0001), 150(\mathrm{p}<0.0001)$, and $180 \mathrm{pA}(\mathrm{p}<0.0001)$ current pulses] (Fig. 1C).

However, female CB1r-KO mice did not show a significant increase in excitability compared to female WT mice (Fig. 1D). Additionally, a significant effect of sex on WT mice across all current pulses was also observed. When comparing sexes, female WT mice showed a significant increase in LC-NE excitability compared to male WT mice [significantly increased excitability responses to $30(\mathrm{p}=0.028), 60(\mathrm{p}=0.020), 90(\mathrm{p}=0.004), 120$ $(\mathrm{p}=0.0003), 150(\mathrm{p}=0.0008)$, and $180 \mathrm{pA}(\mathrm{p}=0.0006)$. No significant effect of sex was observed between CB1r-KO mice at any of the current pulses. Representative traces from each group showing the number of spikes caused by 120pA current pulse: male WT -11 spikes, male $\mathrm{KO}-25$, female $\mathrm{WT}-25$, female $\mathrm{KO}-28$ (Fig. 1A). Slices containing patched cells were processed for immunohistochemistry, to confirm that the data was collected from NE producing cells within the LC. Only cells that were labeled with both 
tyrosine hydroxylase, a marker for NE production in the LC, and biocytin were included in the analyses (Fig. 2). These data provide evidence that genetic deletion of CB1r increases LC-NE neuron excitability in males, increasing the ability of these male CB1r-KO LC-NE cells to respond to excitatory synaptic inputs.

Another way to assess alterations in LC-NE activity is to look at changes in NE production (Fig. 3). Tyrosine hydroxylase (TH) is involved in the rate-limiting step in NE synthesis, and is used as a marker for NE production within the LC. There was a significant effect of genotype on TH expression levels $\left(\mathrm{F}_{1,14}=11.00, \mathrm{p}=0.005\right)$, but no significant effect of sex on TH expression $\left(\mathrm{F}_{1,14}=4.287, \mathrm{p}=0.057\right)$ or interaction sex*genotype on $\mathrm{TH}$ expression $\left(\mathrm{F}_{1,14}=3.753, \mathrm{p}=0.073\right)$. Tukey's post-hoc analysis revealed that WT male mice have significantly lower normalized levels of TH $(0.313 \pm 0.049)$ compared to CB1r/CB2r-KO males $(0.751 \pm 0.064 ; \mathrm{p}=0.011)$ and $\mathrm{KO}$ females $(0.672 \pm 0.061 ; \mathrm{p}=0.009)$, while no significant increase is observed between WT $(0.639 \pm 0.141)$ and KO females $(0.672$ \pm 0.061 ; $\mathrm{p}=0.77$ ) (Fig. 3A). By using an ELISA, it is possible to more precisely determine changes in NE levels in the $\mathrm{mPFC}$, representing a concrete endpoint for the effect of cannabinoid receptor deletion on LC-NE activity. Two-way ANOVA indicated a significant effect of genotype on NE levels $\left(\mathrm{F}_{1,11}=9.719, \mathrm{p}=0.01\right)$, but no significant effect of sex on NE levels $\left(\mathrm{F}_{1,11}=4.825, \mathrm{p}=0.050\right)$ or interaction sex*genotype on NE levels $\left(\mathrm{F}_{1,11}=3.151\right.$, $\mathrm{p}=0.10$ ). Male $\mathrm{CB} 1 \mathrm{r} / \mathrm{CB} 2 \mathrm{r}-\mathrm{KO}$ mice have significantly increased levels of NE in the $\mathrm{mPFC}$ $(0.151 \pm 0.032 \mathrm{pg} / \mathrm{mL} ; \mathrm{p}=0.021)$ compared to all other groups (Fig. 3B): WT males ( 0.049 $\pm 0.008 \mathrm{pg} / \mathrm{mL})$, WT females $(0.039 \pm 0.003 \mathrm{pg} / \mathrm{mL} ; \mathrm{p}=0.012)$, and KO females $(0.071$ $\pm 0.011 \mathrm{pg} / \mathrm{mL} ; \mathrm{p}=0.041)$. There was no significant difference in NE levels between WT and KO females ( $\mathrm{p}=0.79$ ). The Western and ELISA data confirms that deletion of the CB1r causes a significant increase in NE indices in male but not female mice.

\section{Sex differences in cellular adaptations following cannabinoid receptor deletion}

In order to better understand what might be causing the increase in LC-NE activity in male CB1r-KO mice but not females, Western blot analyses were performed to determine what other changes in protein levels might be occurring (Fig. 4). Within the LC, the a2-AR functions to auto-inhibit LC-NE neurons. When examining changes in normalized a2-AR protein levels following CB1r/CB2r deletion (Fig. 4A), a two-way ANOVA determined a significant effect of genotype on a2-AR expression $\left(\mathrm{F}_{1,14}=10.62, \mathrm{p}=0.006\right)$, but no significant effect of $\operatorname{sex}\left(\mathrm{F}_{1,14}=3.004, \mathrm{p}=0.11\right)$ or interaction of sex*genotype $\left(\mathrm{F}_{1,14}=2.927\right.$, $\mathrm{p}=0.11$ ) on a 2 -AR expression. Tukey's post-hoc analysis showed no significant change between WT males $(0.560 \pm 0.027)$ and KO males $(0.721 \pm 0.054$; $\mathrm{p}=0.70)$; however, KO females $(0.720 \pm 0.059)$ showed a significant increase compared to WT females (0.386 \pm 0.098 ; $\mathrm{p}=0.016$ ). CB1r-KO mice have heightened HPA-activity and the LC is involved in the cognitive limb of the stress response; therefore, changes in CRF levels within the LC were also determined (Fig. 4B). Two-way ANOVA revealed a significant effect of genotype on $\mathrm{CRF}$ expression $\left(\mathrm{F}_{1,14}=8.57, \mathrm{p}=0.011\right)$, but no significant effect of sex on CRF expression $\left(\mathrm{F}_{1,14}=0.3233, \mathrm{p}=0.58\right)$ or interaction sex*genotype on CRF expression $\left(\mathrm{F}_{1,14}=1.586\right.$, $\mathrm{p}=0.23$ ). Tukey's post-hoc analysis determined that $\mathrm{CB} 1 \mathrm{r} / \mathrm{CB} 2 \mathrm{r}$ deletion resulted in a significant increase in normalized CRF levels in KO males $(0.467 \pm 0.088)$ compared to WT males $(0.752 \pm 0.062 ; \mathrm{p}=0.045)$, but no significant change was observed between WT $(0.581$ 
$\pm 0.139)$ and KO females $(0.715 \pm 0.059 ; \mathrm{p}=0.65)$. Finally, changes in LC expression of the norepinephrine transporter (NET) were assessed (Fig. 4C). Two-way ANOVA revealed a significant effect of $\operatorname{sex}\left(\mathrm{F}_{1,14}=16.11, \mathrm{p}=0.001\right)$, genotype $\left(\mathrm{F}_{1,14}=13,32, \mathrm{p}=0.003\right)$, and interaction sex* genotype $\left(\mathrm{F}_{1,14}=12.07, \mathrm{p}=0.004\right)$ on LC NET expression. Tukey's post-hoc analysis showed significantly greater expression of NET in WT male mice $(0.893 \pm 0.088)$ compared to all other groups: KO males $(0.541 \pm 0.048$; $\mathrm{p}=0.001)$, WT females $(0.522$ $\pm 0.071 ; \mathrm{p}=0.002)$, and KO females $(0.512 \pm 0.041 ; \mathrm{p}=0.0005)$. Within the $\mathrm{mPFC}$, there was no significant effect of genotype $\left(\mathrm{F}_{1,12}=0.5998, \mathrm{p}=0.45\right)$, sex $\left(\mathrm{F}_{1,12}=0.1215, \mathrm{p}=0.73\right)$, or interaction sex*genotype $\left(\mathrm{F}_{1,12}=3.674, \mathrm{p}=0.08\right)$ on NET expression (Fig. 4D): WT males $(0.842 \pm 0.047)$, KO males $(0.693 \pm 0.070)$, WT females $(0.756 \pm 0.013)$, and KO females $(0.819 \pm 0.036)$. The increase in CRF expression in male KO mice compared to WT and a2AR expression in female KO mice compared to WT might provide some insight into why CB1r-deletion causes an increase in LC-NE excitability in males but not females.

Additionally, basal differences in CB1r expression across sexes could account for the observed electrophysiological differences following CB1r deletion. To investigate this, Western blot analysis on male and female WT mice was performed (Fig. 4E). Two-sample ttest analysis revealed a significant difference in CB1r expression between males $(0.379$ $\pm 0.056)$ and females $\left(0.162 \pm 0.068 ; \mathrm{t}_{10}=2.469, \mathrm{p}=0.033\right)$. Less $\mathrm{CB} 1 \mathrm{r}$ expression in females could be contributing to the increased basal LC-NE excitability in WT females compared to males, as well as the lack of increase in LC-NE excitability in CB1r-KO females compared to WT females.

\section{Loss of CRF-induced increases in LC-NE excitability in CB1r-KO mice}

We determined how CRF affects LC-NE excitability under conditions of CB1r deletion. After baseline measurements were recorded from male and female WT neurons, CRF (300 $\mathrm{nM}$ ) was bath applied and the effect of drug treatment was then recorded. This dose of CRF did not cause a significant increase in the input resistance of male (Fig. 5B) or female (Fig. 5B') WT and CB1r-KO mice when compared to baseline: male WT CRF (274 $\pm 29 \mathrm{M} \Omega)$, male KO CRF ( $417 \pm 52 \mathrm{M} \Omega$ ), female WT CRF ( $259 \pm 43 \mathrm{M} \Omega$ ), and female KO CRF (282 $\pm 48 \mathrm{M} \Omega$ ). Data for neuronal excitability was analyzed using a four-way repeated measure ANOVA/mixed-effects regression model (sex effect by genotype*current pulse, genotype effect by sex*current pulse, genotype effect by drug treatment*current pulse, drug effect by genotype*current pulse) and the following effects were found significant: drug treatment $\left(\mathrm{F}_{1,20}=6.92, \mathrm{p}=0.016\right)$, current pulse $\left(\mathrm{F}_{6,108}=159.27, \mathrm{p}<0.0001\right)$, interaction sex*genotype $\left(\mathrm{F}_{1,18}=10.55, \mathrm{p}=0.005\right)$, interaction genotype $*$ current pulse $\left(\mathrm{F}_{6,108}=4.85, \mathrm{p}=0.0002\right)$, interaction sex*genotype*current pulse $\left(\mathrm{F}_{6,108}=4.80, \mathrm{p}=0.0002\right)$, and interaction genotype*drug treatment $\left(\mathrm{F}_{1,20}=5.48, \mathrm{p}=0.03\right)$, indicating all four factors were important predictors of neuronal excitability. CRF $(300 \mathrm{nM})$ treatment caused a significant increase in LC-NE cell excitability in both male WT (Fig. 5C) and female WT (Fig. 5C') mice, as expected. Tukey post-hoc analyses showed a significant drug treatment effect across WT male and female mice ( $\mathrm{p}=0.0002$ for $30 \mathrm{pA}$ current pulses and $\mathrm{p}<0.0001$ for $60,90,120$, 150 , and $180 \mathrm{pA}$ current pulses). Interestingly, CRF did not cause a significant increase in LC-NE cell excitability in male (Fig. 5D) and female (Fig. 5D') CB1r-KO mice, as the posthoc analyses showed no significant effect of drug treatment across $\mathrm{KO}$ male and female 
mice ( $\mathrm{p} \searrow 0.63$ ). Representative traces from each group showing the number of spikes caused by 120 pA current pulse are provided in figure 5 : male WT baseline -11 spikes, male WT CRF - 16 spikes, male KO baseline -25 , male KO CRF - 28 (Fig. 5A), female WT baseline - 25 baseline, female WT CRF - 33, female KO baseline - 28, female KO CRF - 30 (Fig. 5A). These electrophysiological results suggest that while $300 \mathrm{nM}$ CRF causes a significant increase in LC-NE cell excitability in WT male and female mice, it is not capable of producing the same effect in $\mathrm{CB} 1 \mathrm{r}-\mathrm{KO}$ mice.

When examining single action potentials, CRF administration, sex, and genotype did not affect many of the analyzed characteristics (Table II). Resting membrane potential remained constant among all groups, as did action potential threshold, duration, amplitude, and afterhyperpolarization amplitude. CRF administration did cause a significant decrease in afterhyperpolarization duration in WT males ( $\mathrm{p}=0.004), \mathrm{KO}$ males ( $\mathrm{p}=0.047)$, and WT females $(\mathrm{p}=0.002)$, but not in $\mathrm{KO}$ females ( $\mathrm{p}=0.069)$ (Fig. 6). $\mathrm{CB} 1 \mathrm{r}$ deletion also caused a significant reduction in after- hyperpolarization duration in males ( $\mathrm{p}=0.013$ ), but not in females $(\mathrm{p}=0.29)$.

\section{Discussion}

The present study highlights interesting sex differences in LC neurons following cannabinoid receptor deletion. Electrophysiological studies conducted using an in vitro slice preparation show that $\mathrm{CB} 1 \mathrm{r}$ deletion results in a significant increase in LC-NE excitability in male mice, but not in females. Additionally, male CB1r-KO mice have a significant increase in TH expression in the LC and NE levels in the mPFC compared to WT males, which is not observed in females. Via Western blot analysis, changes in protein expression across genotype and sex were observed. Male CB1r/CB2r-KO mice exhibited an increase in CRF expression and a decrease in NET expression in the LC compared to male WT mice, and female CB1/CB2r-KO mice had an increase in a2-AR levels in the LC compared to female WT mice. Basal differences in CB1r expression were also observed, with male WT mice having higher CB1r levels than female WT mice. Finally, CB1r deletion affected CRFinduced increases in LC-NE activity. Bath application of CRF caused an increase in LC-NE excitability in male and female WT mice; however, the effect of CRF was lost in CB1r-KO mice. When examining individual membrane characteristics, LC-NE cells from male CB1rKO mice showed a decrease in after-hyperpolarization duration. Additionally, CRF treatment caused a further decrease in after-hyperpolarization duration in LC-NE neurons from WT males and CB1r-KO males, and also a decrease in WT females. These data further highlight the importance of the endocannabinoid system in maintaining normal brain adrenergic function, especially in male mice, where CB1r deletion had the most profound effect.

\section{Methodological considerations}

While electrophysiology experiments were carried out in CB1r-KO mice, Western blot and ELISA experiments were carried out in CB1r/CB2r-KO mice due to tissue availability. Many immunohistochemical studies have identified CB1 $\mathrm{r}$ as an abundant protein in the LC, both directly on the noradrenergic neurons as well as on presynaptic afferents synapsing 
onto LC-NE dendrites and cell bodies (Scavone et al., 2010; Wyrofsky et al., 2017). While CB2r is traditionally thought to play a role in the periphery and immune responses (Castillo et al., 2012), growing accumulating evidence suggests that it does in fact play a role in neuronal signaling in some select brain regions (Van Sickle et al., 2005; Gong et al., 2006). However, direct evidence of CB2r on LC-NE neurons has not been shown. Additionally, mixed CB1r/CB2r agonists such as THC, WIN 55,212-2, and CP 55,940 all dosedependently increase LC-NE firing, and their effects are completely blocked by CB1rselective antagonist SR141716A (Mendiguren \& Pineda, 2006; Muntoni et al., 2006). These studies suggest that there is a significantly greater influence of CB1r than CB2r on LC-NE neurons, providing indirect evidence for a minimal role of CB2r signaling in the LC. Therefore, the effects of CB2r deletion in the LC should be less substantial than that of CB1r deletion, and the differences between CB1r-KO mice and CB1r/CB2r-KO mice should be minimal. However, the caveat exists that findings reported here are due to deletion of both receptor phenotypes.

Several studies have reported fluctuations in CB1r mRNA expression and eCB levels across the estrus cycle in several brain regions, including the anterior pituitary (Gonzales et al., 2000) and hypothalamus (Rodriguez de Fonseca et al., 1994), however the effect of ovarian hormones on CB1r and eCB levels in the LC has not been identified. While estrogen might alter the endocannabinoid system, no effect of the estrus cycle was observed in preliminary studies examining the anti-depressant like behavioral effects of CB1r antagonism (Steiner et al., 2008). Additionally, a study specifically examining the LC region controlled for the estrus cycle and found no notable effect of phase on female LC-NE excitability, firing rate, or CRFr1 compartmentalization in both WT and CRF-overexpressing mice (Bangasser et al., 2013). Since no direct effect of estrus cycle was has been found on baseline WT LC-NE excitability, and since the effect of circulating sex hormones on the eCB system is less relevant when CB1r are genetically deleted, we did not note the estrus cycle prior to our experiments, though the caveat exists that controlling for the estrus cycle could alter our results.

Some experimental caveats exist with Western blot and ELISA analysis, including the accuracy of tissue punches and equal protein quantities across various animals and groups. In order to ensure that regions of interest were sampled accurately, one investigator preformed the micropunches for each animal. Additionally, Western blots were probed with GAPDH as an internal standard to ensure equal protein loading for each sample. Results were normalized to GAPDH expression, which was comparable across each animal group examined. Finally, while Western blot analysis allows us to examine changes in protein expression levels, subsequent studies examining changes in mRNA levels could be conducted to further elucidate the effects of $\mathrm{CB} 1 \mathrm{r}$ deletion on noradrenergic indices in the LC.

\section{Basal Differences in LC-NE excitability across sexes}

Whole-cell patch-clamp electrophysiology revealed that female WT mice have increased LC-NE excitability compared to male WT mice. This implies that female WT LC-NE cells have an increased sensitivity to depolarizing stimuli than male WT cells. It is important to 
note that while WT females have heightened excitability, this does not correlate to a heightened basal firing rate. Previous studies by Bangasser et al. similarly found that female WT mice have increased LC-NE excitability compared to males, but the basal firing rate of these neurons is not significantly different across sexes (Bangasser et al., 2013). In corroboration with Bangasser's findings that male and female LC-NE neurons have similar firing rates, our study shows that there is no significant difference in NE levels in the mPFC across sexes - another endpoint for LC-NE firing. While we observe an increase in LC-NE excitability in male $\mathrm{CB} 1 \mathrm{r}-\mathrm{KO}$ mice, we did not examine the basal firing rates between male and female WT and CB1r-KO mice. It would be tempting to postulate that $\mathrm{CB} 1 \mathrm{r}-\mathrm{KO}$ males would also have an increase in LC-NE firing rate compared to the other groups, as they are the only group with increased mPFC NE levels. Subsequent electrophysiology studies could further elucidate this hypothesis.

\section{CB1r-KO increases LC-NE excitability in males but not females}

One of the most interesting and surprising findings from this study is that $\mathrm{CB} 1 \mathrm{r}$ deletion affected LC-NE excitability selectively in male subjects. The changes observed in input resistance and after-hyperpolarization (AHP) duration across sex and genotype are consistent with the changes observed in LC-NE excitability. All groups that had heightened LC-NE excitability also showed a decrease in AHP duration: CB1r-KO males and WT females compared to WT males, CRF treated WT males and females compared to baseline. Additionally, CB1r-KO male and CRF treated WT males and females all had an increase in input resistance, suggesting a decrease in ion channel conductance. Neuronal increases in 3', 5 '-cyclic adenosine monophosphate (cAMP) cause increased $\mathrm{Ca}^{2+}$ efflux. $\mathrm{Ca}^{2+}$-mediated increases in $\mathrm{K}^{+}$conductance occur in LC-NE cells, leading to more rapid repolarization (Adams et al., 1982; Osmanovic and Shefner, 1993; Nestler et al., 1999). An increased repolarization rate corresponds with a shorter AHP duration, and suggests a general decrease in overall $\mathrm{K}^{+}$ion conductance (Adams et al., 1982). Results from the Western blot analysis provide further insight into why only certain groups had increased excitability.

In males, a potential mechanism underlying increased LC-NE excitability involves differences in CRF expression. Interestingly, only male $\mathrm{CB} 1 \mathrm{r} / \mathrm{CB} 2 \mathrm{r}-\mathrm{KO}$ mice showed an increase in CRF expression in the LC when compared to WT and female subjects. This was surprising initially, since many studies have shown that CB1-KO mice have heightened HPA axis activity and increased vulnerability to chronic stress (Martin et al., 2002; Uriguen et al., 2004), and female rodents are known to have increased susceptibility to stressors compared to males (Bangasser and Valentino, 2012; Handa and Weiser, 2014). However, more recent studies examining mice of both sexes report that females do not show HPA axis hyperactivity to the same degree as males following CB1r deletion or antagonism (Atkinson et al., 2010; Roberts et al., 2014). Thus, since the LC-NE cognitive limb of the stress response is engaged in parallel with the HPA axis (Van Bockstaele et al., 1998, Valentino and Van Bockstaele, 2008), it is tempting to speculate that female CB1r-KO mice might show less of an increase in CRF release in the LC compared to males. CRF binds to its receptor, CRFr1, on LC-NE neurons and increases LC-NE firing rate (Curtis et al., 1996). Both acute and chronic stress up-regulate the cAMP pathway (Nestler and Aghajanian, 1997), which, through downstream effects, increases neuronal re-polarization and decreases 
LC-NE AHP duration (Adams et al., 1982; Nestler et al., 1999). Therefore, increased CRF expression represents one mechanism by which $\mathrm{CB} 1 \mathrm{r}-\mathrm{KO}$ males might have increased LCNE excitability while female CB1r-KO mice do not (Fig. 7B).

Another potential mechanism underlying the observed sex differences in this study involves alterations in a2-AR expression between female $\mathrm{CB} 1 \mathrm{r} / \mathrm{CB} 2 \mathrm{r}-\mathrm{KO}$ and WT mice. NE released from recurrent collaterals of LC neurons can bind to postsynaptic a2-AR on the LC-NE dendrites resulting in auto-inhibition (Lee et al., 1998a, b). In response, an increase in a2AR would result in a decrease in cAMP and inhibition of LC-NE neurons, which is characterized by an increase in AHP and decrease in input resistance (Korf et al., 1973). While CB1r/CB2r deletion does not affect a 2-AR levels in males, it does cause a significant increase in a 2-AR expression in females. This could represent a compensatory mechanism in females, where another inhibitory receptor, a2-AR, is up-regulated to compensate for the loss of another inhibitory receptor, $\mathrm{CB} 1 \mathrm{r}$ (Fig. 7B'). This results in comparable excitability levels across LC-NE neurons, input resistance, and AHP duration in CB1r-KO and WT females.

Lastly, the observed sex difference in basal CB1r expression is likely a key contributor to the electrophysiological variances across sexes. While there is conflicting data surrounding the effects of CB1r antagonists on LC-NE activity, studies performed on male rodents show that they do alter LC-NE firing, suggesting there is tonic eCB activity in males (Carvalho \& Van Bockstaele, 2012; Wyrofsky et al., 2015). One study found that a low dose of a CB1r antagonist resulted in an increase in NE release in the mPFC (Tzavara et al., 2003). This mimics what was observed in the male $\mathrm{CB} 1 \mathrm{r}-\mathrm{KO}$ mice, where abolishing $\mathrm{CB} 1 \mathrm{r}$ signaling receptor deletion caused an increase in NE release. One final reason why female CB1r-KO mice might not have shown a significant increase in LC-NE excitability and NE efflux could be because they have less CB1r expression, so their deletion would have less profound of an effect on LC cells compared to males. Future studies examining the effect of CB1r antagonists in females would provide additional support for this hypothesis. Additionally, while less CB1r expression could indicate less tonic eCB signaling in the female $\mathrm{LC}$, it is important to note that other $\mathrm{eCB}$ proteins play a role as well. Basal differences in FAAH and other eCB metabolic proteins might also exist between males and females, further implicating a difference in tonic eCB regulation of the LC. Subsequent Western blot analyses investigating their expression should be performed to determine their contribution to changes in LC-NE excitability across sexes and genotype.

\section{Loss of CRF-mediated responses in CB1r-KO mice}

Although CRF is known to modulate LC-NE neurons and increase their firing rate (Curtis et al., 1996; Valentino et al., 1997; Jedema and Grace, 2004), and this study confirmed that 300 nM CRF bath application is capable of doing so in LC neurons from WT males and females, this effect was not observed in CB1r-KO mice. This loss of CRF-mediated increases in LCNE excitability in male CB1r-KO mice could be due to the increased endogenous CRF levels saturating CRFr1, rendering the exogenous application of oCRF ineffective (Fig. 7C). In female CB1r-KO mice, the lack of CRF-induced responses might be attributed to the 
increased a 2-AR expression, causing local auto-inhibition and attenuation of LC-NE activity following oCRF administration (Fig. 7C').

Additionally, chronic stress has been shown to alter CRFr1 trafficking in a sex dependent manner, with males exhibiting increased stress-induced internalization while females exhibit stress-induced recruitment to the plasma membrane (Bangasser et al., 2010; Valentino et al., 2013). It is possible that increased HPA hyperactivity (Uriguen et al., 2004) and a chronic increase in CRF levels in the LC of male CB1r-KO mice could lead to sustained desensitization of CRF receptors. Immunoelectron microscopy experiments examining CRF receptor trafficking in LC-NE neurons of male and female CB1r-KO mice could provide further insight into changes in the stress circuitry following CB1r deletion.

\section{Implications for pharmacotherapies}

Dysregulation of NE is a key component in the development of anxiety and other stressinduced psychiatric disorders (Carvalho and Van Bockstaele, 2012). Furthermore, reduction in NET expression in the LC has been identified in individuals suffering from major depression and PTSD (Klimek et al., 1997; Pietrzak et al., 2013). While acute stress does not affect NET levels, chronic and repeated stress exposure can lead to downregulation (Zafar et al., 1997). Increased turnover and NE depletion, which can occur following a stressor (Korf et al., 1973), also leads to the downregulation of NET and upregulation of TH, and increased TH levels in the LC have also been correlated with the development of depression (Klimek et al., 1997). Male CB1r/CB2r-KO mice exhibit a decrease in NET and an increase in TH expression, while no change was observed between female $\mathrm{CB} 1 \mathrm{r} / \mathrm{CB} 2 \mathrm{r}-\mathrm{KO}$ and WT mice. These findings suggest that $\mathrm{CB} 1 \mathrm{r}$ deletion or chronic antagonism may be more detrimental to males than females, creating a microenvironment in the LC of male $\mathrm{KO}$ mice that mimics conditions of chronic stress.

In addition to cellular adaptations that occur following cannabinoid receptor deletion, the lack of increase in LC-NE excitability in female CB1r-KO mice could be due to less basal eCB signaling in females. If the female $\mathrm{LC}$ is under less tonic regulation by eCBs, then removal of $\mathrm{CB} 1 \mathrm{r}$ might have less profound of an effect. In the amygdala, basal differences in the eCB system have been observed across sex, with males having greater levels of 2-AG and AEA, while females have increased expression of the enzymes responsible for their degradation (Krebs-Kraft et al., 2010; Craft et al., 2013). A similar phenomenon might exist in the LC, and future Western blot and ELISA analyses of 2-AG, AEA, and their metabolic and synthesizing enzymes would provide further insight into potential basal sex differences.

We have demonstrated in previous studies that CB1r are localized to CRF-containing afferents from the amygdala, and their presynaptic distribution in the peri-LC suggests that they might be capable of attenuating CRF release via activation by endogenous or exogenous cannabinoids. A working model (Fig. 7A) is that CRF released from amygdalar afferents binds to postsynaptic CRFr1 on LC-NE neurons, causing membrane depolarization and increase in LC-NE excitability. However, the influx of $\mathrm{Ca}^{2+}$ then stimulates the synthesis and release of eCBs, which in turn retrogradely traverse the synapse. They then bind to presynaptic CB1r on CRF-containing amygdalar axon terminals, aiding in the suppression of subsequent CRF release and helping return LC-NE activity back to baseline. 
CB1r antagonists and inverse agonists have been investigated for a variety of disorders ranging from obesity to schizophrenia (Wyrofsky et al., 2015). Rimonabant, a CB1r antagonist originally used for the treatment of obesity, was discontinued due to adverse psychological side effects (Nissen et al., 2008). Based on the results obtained in this study, $\mathrm{CB} 1 \mathrm{r}$ antagonism might not cause an increase in LC-NE excitability to the same degree in females that it would in males, and the effects from CB1r antagonist treatment might be less significant in females, highlighting the importance of using both genders when performing pre-clinical trials. Indeed, this would be in line with analyses performed on the adverse effects of rimonabant, which suggest that the odds ratio for developing depression after taking this CB1r antagonist was greatest in males aged 35-38 (Pi-Sunyer et al., 2006; Nissen et al., 2008). This study adds to the growing literature that dysregulation of the cannabinoid system can lead to the dysregulation of noradrenergic signaling, especially in males, helping to advance our understanding of how these systems could be targeted for more effective treatment of psychological disorders.

\section{Acknowledgements}

This project was supported by the National Institutes of Health grants DA020129 to E.J. Van Bockstaele and P30 DA013429 to L.G. Kirby.

\section{Abbreviations}

2-AG

aCSF

AEA

AHP

ANOVA

AP

AR

cAMP

CB1r

CB2r

CRF

CRFr1

eCB

ELISA

FAAH

GAPDH 2-arachidonylglycerol

artificial cerebrospinal fluid

$\mathrm{N}$-arachidonylethanolamide/anandamide

afterhyperpolarization potential

analyses of variance

action potential

adrenoceptor

cyclic adenosine monophosphate

cannabinoid type 1 receptor

cannabinoid type 2 receptor

corticotropin releasing factor

corticotropin releasing factor receptor type 1

endocannabinoid

enzyme-linked immunosorbent assay

fatty acid amide hydrolase

glyceraldehyde 3-phosphate dehydrogenase

Eur J Neurosci. Author manuscript; available in PMC 2019 September 01. 


$\begin{array}{ll}\text { HPA } & \text { hypothalamic-pituitary adrenal (axis) } \\ \text { KO } & \text { knockout } \\ \text { LC } & \text { locus coeruleus } \\ \text { mPFC } & \text { medial prefrontal cortex } \\ \text { mRNA } & \text { messenger ribonucleic acid } \\ \text { NE } & \text { norepinephrine } \\ \text { NET } & \text { norepinephrine transporter } \\ \text { OCRF } & \text { ovine corticotropin releasing factor } \\ \text { PTSD } & \text { posttraumatic stress disorder } \\ \text { PVDF } & \text { polyvinylidene difluoride } \\ \text { SEM } & \text { standard error of mean } \\ \text { TH } & \text { tyrosine hydroxylase } \\ \text { THC } & \Delta-9 \text { tetrahydrocannabinol } \\ \text { WT } & \text { wild type }\end{array}$

\section{References}

Adams P, Constanti A, Brown D, \& Clark R (1982) Intracellular Ca2+ activates a fast voltage-sensitive $\mathrm{K}+$ current in vertebrate sympathetic neurones. Nature, 296:746-749. [PubMed: 6280066]

Aso E, Ozaita A, Valdizan EM, Ledent C, Pazos A, Maldonado R, \& Valverde O (2008) BDNF impairment in the hippocampus is related to enhanced despair behavior in CB1 knockout mice. J. Neurochem, 105:565-572. [PubMed: 18047561]

Aston-Jones G \& Cohen JD (2005) An integrative theory of locus coeruleus-norepinephrine function: adaptive gain and optimal performance. Annu. Rev. Neurosci, 28:403-450. [PubMed: 16022602]

Atkinson H, Leggett J, Wood S, Castrique E, Kershaw Y, \& Lightman SL (2010) Regulation of the hypothalamic-pituitary-adrenal axis circadian rhythm by endocannabinoids is sexualy diergic. Endocrinology, 151:3720-3727. [PubMed: 20534730]

Bangasser DA, Curtis A, Reyes BA, Bethea TT, Parastatidis I, Ischiropoulos H, Van Bockstaele EJ, \& Valentino RJ (2010) Sex differences in corticotropin-releasing factor receptor signaling and trafficking: potential role in female vulnerability to stress-related psychopathology. Mol. Psychiatry, 15:877-904. [PubMed: 20548297]

Bangasser DA, Reyes BA, Piel D, Garachh V, Zhang X-Y, \& Plona Z (2013) Increased vulnerability of the brain norepinephrine system of females to corticotropin-releasing factor overexpression. Mol. Psychiatry, 18:166-173. [PubMed: 22508464]

Bangasser DA \& Valentino RJ (2012) Sex differences in molecular and cellular substrates of stress. Cell. Mol. Neurobiol, 32:709-723. [PubMed: 22488525]

Barna I, Zelena D, Arszovszki AC, \& Ledent C (2004) The role of endogenous cannabinoids in the hypothalamo-pituitary-adrenal axis regulation: in vivo and in vitro studies in CB1 receptor knockout mice. Life Sci, 75:2959-2970. [PubMed: 15454346]

Befort K (2015) Interactions of the opioid and cannabinoid systems in reward: insights from knockout studies. Front. Pharmacol, 6(6):1-15. [PubMed: 25805991] 
Carvalho AF, Mackie K, \& Van Bockstaele EJ (2010) Cannabinoid modulation of limbic forebrain noradrenergic circuitry. Eur. J. Pharmacol, 31:286-301.

Carvalho AF \& Van Bockstaele EJ (2012) Cannabinoid modulation of noradrenergic circuits: Implications for psychiatric disorders. Prog. Neuropharmacol. Biol. Psychiatry, 38:59-67.

Castillo PE, Younts TJ, Chavez AE, \& Hashimotodani Y (2012) Endocannabinoid signaling and synaptic function. Neuron, 76:70-81. [PubMed: 23040807]

Cathel AM, Reyes BA, Wang Q, Palma J, Mackie K, Van Bockstaele EJ, \& Kirby LG (2014) Cannabinoid modulation of alpha2 adrenergic receptor function in rodent medial prefrontal cortex. Eur. J. Neurosci, 40(8):3202-3214. [PubMed: 25131562]

Cohen H, Liu T, Kozlovsky N, Kaplan Z, Zohar J, \& Mathe A (2012) The neuropeptide Y (NPY)-ergic system is associated with behavioral resilience to stress exposure in an animal model of posttraumatic stress disorder. Neuropsychopharmacology, 37:350-363. [PubMed: 21976046]

Cossu G, Ledent C, Fattore L, Imperato A, Bohme G, Parmentier M, \& Fratta W (2001) Cannabinoid CB 1 receptor knockout mice fail to self-administer morphine but not other drugs of abuse. Behav. Brain. Res, 118:61-65. [PubMed: 11163634]

Cota D (2008) The role of the endocannabinoid system in the regulation of the hypothalamic-pituitaryadrenal axis activity. J. Neuroendocrinol, 20:35-38. [PubMed: 18426497]

Craft RM, Marusich JA, \& Wiley JL (2013) Sex differences in cannabinoid pharmacology: A reflection of differences in the endocannabinoid system. Life Sci, 92:476-481. [PubMed: 22728714]

Curtis A, Bello NT, \& Valentino RJ (2001) Evidence for functional release of endogenous opioids in the locus ceruleus during stress termination. J. Neurosci, 21:1-5.

Curtis A, Lechner SM, Pavcovich LA, \& Valentino RJ (1996) Activation of the locus coeruleus noradrenergic system by intracoerulear microinfusion of corticotropin-releasing factor: effects on discharge rate, cortical norepinephrine levels and cortical electroencephalographic activity. J. Pharmacol. Exp. Ther, 281:163-172.

Curtis A, Leiser SC, Snyder K, \& Valentino RJ (2012) Predator stress engages corticotropin-releasing factor and opioid systems to alter the operating mode of locus coeruleus norepinephrine neurons. Neuropharmacology, 62:1737-1745. [PubMed: 22210331]

Di Marzo V (2008) Targeting the endocannabinoid system: to enahnce or reduce? Nat. Rev. Drug Discov, 7:438-455. [PubMed: 18446159]

Di Marzo V, Bifulco M, \& De Petrocellis L (2004) The endocannabinoid system and its therapeutic exploitation. Nat. Rev. Drug Discov, 3:771-784. [PubMed: 15340387]

Fattore L, Spano M, Altea S, Angius F, Fadda P, \& Fratta W (2007) Cannabinoid self-administration in rats: sex differences and the influence of ovarian function. Brit. J. Pharmacol, 152:795-804. [PubMed: 17891164]

Gobbi G, Bambico FR, Mangieri R, Bortolato M, Campolongo P, Solinas M, Cassano M, Morgese MG, Debonnel G, Duranti A, Tontini A, Tarzia G, Mor M, Trezza V, Goldberg SR, Cuomo V, \& Piomelli D (2005) Antidepressant-like activity and modulation of brain monoaminergic transmission by blockade of anandamide hydrolysis. Proc. Natl. Acad. Sci. U.S.A, 102:18620 18625. [PubMed: 16352709]

Gong J-P, Onaivi ES, Ishiguro H, Liu Q-R, Tagliaferro PA, Brusco A, \& Uhl GR (2006) Cannabinoid CB2 receptors: immunohistochemical localization in rat brain. Brain Res, 1071:10-23. [PubMed: 16472786]

Gonzales S, Bisogno T, Wenger T, Manzanares J, Milone A, Berrendero F, Di Marzo V, Ramos JA, \& Fernandez-Ruiz J (2000) Sex steroid influence on cannabinoid CB1 receptor mRNA and endocannabinoid levels in the anterior pituitary gland. Biochem. Biophys. Res. Commun, 270:260-266. [PubMed: 10733937]

Green B, Kavanagh D, \& Young R (2003) Being stoned: a review of self-reported cannabis effects. Drug Alcohol Rev, 22:453-460. [PubMed: 14660135]

Handa R \& Weiser M (2014) Gonadal steroid hormones and the hypothalamo-pituitary-adrenal axis. Front. Neuroendocrinol, 35:197-220. [PubMed: 24246855]

Heilig M (2004) The NPY system in stress, anxiety and depression. Neuropeptides, 38:213-224. [PubMed: 15337373] 
Hill MN \& Gorzalka BB (2009) The endocannabinoid system and the treatment of mood and anxiety disorders. C.N.S. Neurol. Disord. Drug Targets, 8:451-458.

Hill MN \& McEwen BS (2009) Endocannabinoids: the silent partner of glucocorticoids in the synapse. Proc. Natl. Acad. Sci, 106:4579-4580. [PubMed: 19293387]

Hill MN, McLaughlin RJ, Bingham B, Shrestha L, Lee TT-Y, Gray JM, Hillard CJ, Gorzalka BB, \& Viau V (2010a) Endogenous cannabinoid signaling is essential for stress adaptation. Proc. Natl. Acad. Sci, 107:9406-9411. [PubMed: 20439721]

Hill MN, Patel S, Campolongo P, Tasker JG, Wotjak CT, \& Bains JS (2010b) Functional interactions between stress and the endocannabinoid system: from synaptic signaling to behavioral output. J. Neurosci, 30:14980-14986. [PubMed: 21068301]

Jedema H \& Grace A (2004) Corticotropin-releasing hormone directly activates noradrenergic neurons of the locus coeruleus recorded in vitro. J. Neurosci, 24:9703-9713. [PubMed: 15509759]

Kask A, Rago L, \& Harro J (1998) Anxiolytic-like effect of neuropeptide Y (NPY) and NPY 13-36 microinjected into vicinity of locus coeruleus in rats. Brain Res, 788:345-348. [PubMed: 9555090]

Klimek V, Stockmeier C, Overholser J, Meltzer HY, Kalka S, Dilley G, \& Ordway G (1997) Reduced levels of norepinephrine transporters in the locus coeruleus in major depression. J. Neurosci, 17:8451-8458. [PubMed: 9334417]

Korf J, Aghajanian GK, \& Roth RH (1973) Increased turnover of norepinephrine in the rat cerebral cortex during stress: role of the locus coeruleus. Neuropharmacology, 12:933-938. [PubMed: 4750561]

Krebs-Kraft D, Hill MN, Hillard CJ, \& McCarthy M (2010) Sex differences in cell proliferation in developing rat amygdala mediated by endocannabinoids has implications for social behavior. Proc. Natl. Acad. Sci. U.S.A, 107:20535-20540. [PubMed: 21059913]

Lee A, Rosin D, \& Van Bockstaele EJ (1998a) a 2A-adrenergic receptors in the rat nucleus locus coeruleus: subcellular localization in catecholaminergic dendrites, astrocytes, and presynaptic axon terminals. Brain Res, 795:157-169. [PubMed: 9622618]

Lee A, Rosin D, \& Van Bockstaele EJ (1998b) Ultrastructural evidence for prominent postsynaptic localization of a2c-adrenergic receptors in the catecholaminergic dendrites in the rat nucleus locus coeruleus. J. Comp. Neurol, 394:218-229. [PubMed: 9552127]

Martin M, Ledent C, Parmentier M, Maldonado R, \& Valverde O (2002) Involvement of CB1 cannabinoid receptors in emotional behavior. Psychopharmacology, 159:379-387. [PubMed: 11823890]

Mendiguren A \& Pineda J (2006) Systemic effect of cannabinoids on the spontaneous firing rate of locus coeruleus neurons in rats. Eur. J. Pharmacol, 534:83-88. [PubMed: 16483566]

Mueller D \& Cahill SP (2010) Noradrenergic modulation of extinction learning and exposure therapy. Behav. Brain Res, 208:1-11. [PubMed: 19931568]

Mueller D, Porter JT, \& Quirk GJ (2008) Noradrenergic signaling in infralimbic cortex increases cell excitability and strengthens memory for fear extinction. J. Neurosci, 28:369-375. [PubMed: 18184779]

Muntoni AL, Pillolla G, Melis M, Perra S, Gessa GL, \& Pistis M (2006) Cannabinoids modulate spontaneous neuronal activity and evoked inhibition of locus coeruleus noradrenergic neurons. Eur. J. Pharmacol, 23:2385-2394.

Navarro M, Carrera M, Fratta W, Valverde O, Cossu G, Fattore L, Chowen J, Gomez R, Del Arco I, Villanua M, \& Maldonado R (2001) Functional interaction between opioid and cannabinoid receptors in drug self-administration. J. Neurosci, 21:55344-55350.

Nestler E \& Aghajanian GK (1997) Molecular and cellular basis of addiction. Science, 278:58-63. [PubMed: 9311927]

Nestler E, Alreja M, \& Aghajanian GK (1999) Molecular control of locus coeruleus neurotransmission. Biol. Psychiatry, 46:1131-1139. [PubMed: 10560020]

Nissen SE, Nicholls SJ, Wolski K, Rodes-Cabau J, Cannon CP, Deanfield JE, Despres JP, Kastelein JJ, Steinhubl SR, Kapadia S, Yasin M, Ruzyllo W, Gaudin C, Job B, Hu B, Bhatt DL, Lincoff AM, \& Tuzcu EM (2008) Effect of rimonabant on progression of atherosclerosis in patients with 
abdominal obesity and coronary artery disease: the STRADIVARIUS randomized controlled trial. J.A.M.A, 299:1547-1560.

Oropeza VC, Page ME, \& Van Bockstaele EJ (2005) Systemic administration of WIN 55,212-2 increases norepinephrine release in the rat frontal cortex. Brain Res, 1046:45-54. [PubMed: 15927549]

Osmanovic S \& Shefner S (1993) Calcium-activated hyperpolarization in rat locus coeruleus neurons in vitro. J. Physiol, 469:89-109. [PubMed: 7903697]

Page ME, Oropeza VC, \& Van Bockstaele EJ (2008) Local administration of a cannabinoid agonist alters norepinephrine efflux in the rat frontal cortex. Neurosci. Lett, 431:1-5. [PubMed: 18055114]

Parolaro D, Realini N, Vigano D, Guidali C, \& Rubino T (2010) The endocannabinoid system and psychiatric disorders. Exp. Neurol, 224:3-14. [PubMed: 20353783]

Patel KD \& Hillard CJ (2003) Cannabinoid-induced fos expression within A10 dopaminergic neurons. Brain Res, 963:15-25. [PubMed: 12560108]

Pattij T, Wiskerke J, \& Schoffelmeer A (2008) Cannabinoid modulation of executive functions. Eur. J. Pharmacol, 585:458-463. [PubMed: 18423599]

Pi-Sunyer F, Aronne L, Heshmati H, Devin J, \& Rosenstock J (2006) Effect of rimonabant, a cannabinoid-1 receptor blocker, on weight and cardiometabolic risk factors in overweight of obese patients: RIO-North America: a randomized controlled trial. J.A.M.A, 295:761-775.

Pietrzak RH, Gallezot J, Ding Y, Henry S, Potenza M, Southwick SM, Krystal J, Carson R, \& Neumeister A (2013) Association of posttraumatic stress disorder with reduced in vivo norepinephrine transporter availability in the locus coeruleus. J.A.M.A. Psychiatry, 70:1199-1205.

Poddar MK \& Dewey WL (1980) Effects of cannabinoids on catecholamine uptake and release in hypothalamic and striatal synaptosomes. J. Pharmacol. Exp. Ther, 214:63-67. [PubMed: 7391971]

Reilly D, Didcott P, Swift W, \& Hall W (1998) Long-term cannabis use: characteristics of users in an Australian rural area. Addiction, 93:837-846. [PubMed: 9744119]

Reyes BAS, Carvalho AF, Szot P, Kalamarides DJ, Wang Q, Kirby LG, \& Van Bockstaele EJ (2017) Cortical adrenoceptor expression, function and adaptation under conditions of cannabinoid receptor deletion. Exp. Neurol, 292:179-192. [PubMed: 28341460]

Reyes BAS, Drolet G, \& Van Bockstaele EJ (2008) Dynorphin and stress-related peptides in rat locus coeruleus: contribution of amygdalar efferents. J. Comp. Neurol, 508:663-675. [PubMed: 18381633]

Reyes BAS, Heldt NA, Mackie K, Van Bockstaele EJ (2015) Ultrastructural evidence for synaptic contacts between noradrenergic afferents and endocannabinoid-synthesizing post-synaptic neurons. Neurosci, 303:323-337.

Reyes BAS, Szot P, Sikkema C, Cathel AM, Kirby LG, \& Van Bockstaele EJ (2012) Stress-induced sensitization of cortical adrenergic receptors following a history of cannabinoid exposure. Exp. Neurol, 236:327-335. [PubMed: 22677142]

Roberts CJ, Stuhr KL, Hutz MJ, Raff H, \& Hillard CJ (2014) Endocannabinoid signaling in hypothalamic-pituitary-adrenocortical axis recovery following stress: effects of indirect agonists and comparison of male and female mice. Pharmacol. Biochem. Behav, 117:17-24. [PubMed: 24316201]

Rodriguez de Fonseca F, Cebeira M, Martin M, \& Fernandez-Ruiz J (1994) Cannabinoid receptors in rat brain areas: sexual differences, fluctuations during estrous cycle and changes after gonadectomy and sex steroid replacement. Life Sci, 54(3):159-170. [PubMed: 8289577]

Sara SJ (2009) The locus coeruleus and noradrenergic modulation of cognition. Nat. Rev. Neurosci, 10:211-223. [PubMed: 19190638]

Scavone JL, Mackie K, \& Van Bockstaele EJ (2010) Characterization of cannabinoid-1 receptors in the locus coeruleus: relationship with mu-opioid receptors. Brain Res, 1312:18-31. [PubMed: 19931229]

Serova L, Tillinger A, Alaluf M, Laukova M, Keegan K, \& Sabban E (2013) Single intranasal neuropeptide $\mathrm{Y}$ infusion attenuates development of PTSD-like symptoms to traumatic stress in rats. Neuroscience, 236:298-312. [PubMed: 23376740] 
Steiner H, Bonner TI, Zimmer AM, Kitai S, \& Zimmer A (1999) Altered gene expression in striatal projection neurons in CB1 cannabinoid receptor knockout mice. Proc. Natl. Acad. Sci. U.S.A, 96(10):5786-5790. [PubMed: 10318962]

Steiner MA, Wanisch K, Monory K, Marsicano G, Borroni E, Bachli H, Holsboer F, Lutz B, \& Wotjak CT (2008) Impaired cannabinoid receptor type 1 signaling interferes with stress-coping behavior in mice. Pharmacogenomics J, 8:196-208. [PubMed: 17684478]

Tjoumakaris SI, Rudoy CA, Peoples J, Valentino RJ, \& Van Bockstaele EJ (2003) Cellular interactions between axon terminals containing endogenous opioid peptides or corticotropin-releasing factor in the rat locus coeruleus and surrounding dorsal pontine tegmentum. J. Comp. Neurol, 466:445-456. [PubMed: 14566941]

Tzavara ET, Davis RJ, Perry KW, Li X, Salhoff C, Bymaster FP, Witkin J, \& Nomikos G (2003) The CB1 receptor antagonist ST141716A selectively increases monoaminergic neurotransmission in the medial prefrontal cortex; implications for therapeutic actions. Brit. J. Pharmacol, 138:544-553. [PubMed: 12598408]

Tzavara ET, Perry KW, Rodriguez DE, Bymaster FP, \& Nomikos G (2001) The cannabinoid CB(1) receptor antagonist SR141716A increases norepinephrine outflow in the rat anterior hypothalamus. Eur. J. Pharmacol, 426:R3-4. [PubMed: 11527547]

Uriguen L, Perez-Rial S, Ledent C, Palomo R, \& Manzanares J (2004) Impaired action of anxiolytic drugs in mice deficient in cannabinoid CB1 receptors. Neuropharmacology, 46:966-973. [PubMed: 15081793]

Valentino RJ, Bangasser DA, \& Van Bockstaele EJ (2013) Sex-biased stress signaling: the corticotropin-releasing factor receptor as a model. Mol. Pharmacol, 83:737-745. [PubMed: 23239826]

Valentino RJ, Curtis A, Page ME, Pavcovich LA, \& Florin-Lechner S (1997) Activation of the locus coeruleus brain noradrenergic system during stress: circuitry, consequences, and regulation. Adv. Pharmacol, 42:781-784.

Valentino RJ \& Van Bockstaele EJ (2008) Convergent regulation of locus coeruleus activity as an adaptive response to stress. Eur. J. Pharmacol, 583:194-203. [PubMed: 18255055]

Van Bockstaele EJ, Bajic D, Proudfit H, \& Valentino RJ (2001) Topographic architecture of stressrelated pathways targeting the noradrenergic locus coeruleus. Physiol. Behav, 73:273-283. [PubMed: 11438352]

Van Bockstaele EJ, Chan J, \& Pickel VM (1996) Input from central nucleus of the amygdala efferents to pericoerulear dendrites, some of which contain tyrosine hydroxylase immunoreactivity. J. Neurosci, 45:289-302.

Van Bockstaele EJ, Colago EEO, \& Valentino RJ (1998) Amygdaloid corticotropin-releasing factor targets locus coeruleus dendrites: substrate for the coordination of emotional and cognitive limbs of the stress response. J. Neuroendocrinol, 10:743-757. [PubMed: 9792326]

Van Bockstaele EJ, Peoples J, \& Valentino RJ (1999) Anatomic basis for differential regulation of the rostrolateral peri-locus coeruleus region by limbic afferents. Biol. Psychiatry, 46:1352-1363. [PubMed: 10578450]

Van Bockstaele EJ, Saunders A, Commons KG, Liu XB, \& Peoples J (2000) Evidence for coexistence of enkephalin and glutamate in axon terminals and cellular sites for functional interactions of their receptors in the rat locus coeruleus. J. Comp. Neurol, 417:103-114. [PubMed: 10660891]

Van Sickle MD, Duncan M, Kingsley PJ, Mouihate A, Urbani P, Mackie K, Stella N, Makriyannis A, Piomelli D, Davison JS, Marnett LJ, Di Marzo V, Pittman QJ, Patel KD, \& Sharkey KA (2005) Identification and functional characterization of brainstem cannabinoid CB2 receptors. Science, 310:329-332. [PubMed: 16224028]

Velez CN, Johnson J, \& Cohen PA (1989) A longitudinal analysis of selected risk factors for childhood psychopathology. J. Am. Acad. Child Adolesc. Psychiatry, 28:861-864. [PubMed: 2808256]

Viveros MP, Marco EM, Llorente R, \& Lopez-Gallardo M (2007) Endocannabinoid system and synaptic plasticity: implications for emotional responses. Neural Plast, 2007:52908. [PubMed: 17641734] 
Warner M, Reyes BA, \& Van Bockstaele EJ (2016) Cellular substrates for interactions between neuropeptide Y (NPY) and corticotropin-releasing factor (CRF) in the rat locus coeruleus. Society for Neuroscience poster.

Williams J \& North R (1984) Opiate receptor interactions on single locus coeruleus neurons. Mol. Pharmacol, 26(3):489-497. [PubMed: 6092898]

Williams J, North R, Shefner S, Nishi S, \& Egan T (1984) Membrane properties of rat locus coeruleus neurons. Neuroscience, 13:137-156. [PubMed: 6493483]

Witkin J, Tzavara E, \& Nomikos G (2005) A role for cannabinoid CB1 receptors in mood and anxiety disorders. Behav. Pharmacol, 16:315-331. [PubMed: 16148437]

Wyrofsky RR, McGonigle P, \& Van Bockstaele EJ (2015) Drug discovery strategies that focus on the endocannabinoid signaling system in psychiatric disease. Expert Opin. Drug Discov, 10:17-36. [PubMed: 25488672]

Wyrofsky RR, Reyes BAS, \& Van Bockstaele EJ (2017) Co-localization of the cannabinoid type 1 receptor with corticotropin-releasing factor-containing afferents in the noradrenergic nucleus locus coeruleus: implications for the cognitive limb of the stress response. Brain Struct. Func, 222(7): 3007-3023.

Zafar H, Pare W, \& Tejani-Butt SM (1997) Effect of acute or repeated stress on behavior and brain norepinephrine system in Wistar-Kyoto (WKY) rats. Brain Res. Bull, 44:289-295. [PubMed: 9323444]

Zimmer A, Zimmer AM, Hohmann AG, Herkenham M, \& Bonner TI (1999) Increased mortality, hypoactivity, and hypoalgesia in cannabinoid CB1 receptor knockout mice. Proc. Natl. Acad. Sci. U.S.A, 96:5780-5785. [PubMed: 10318961] 

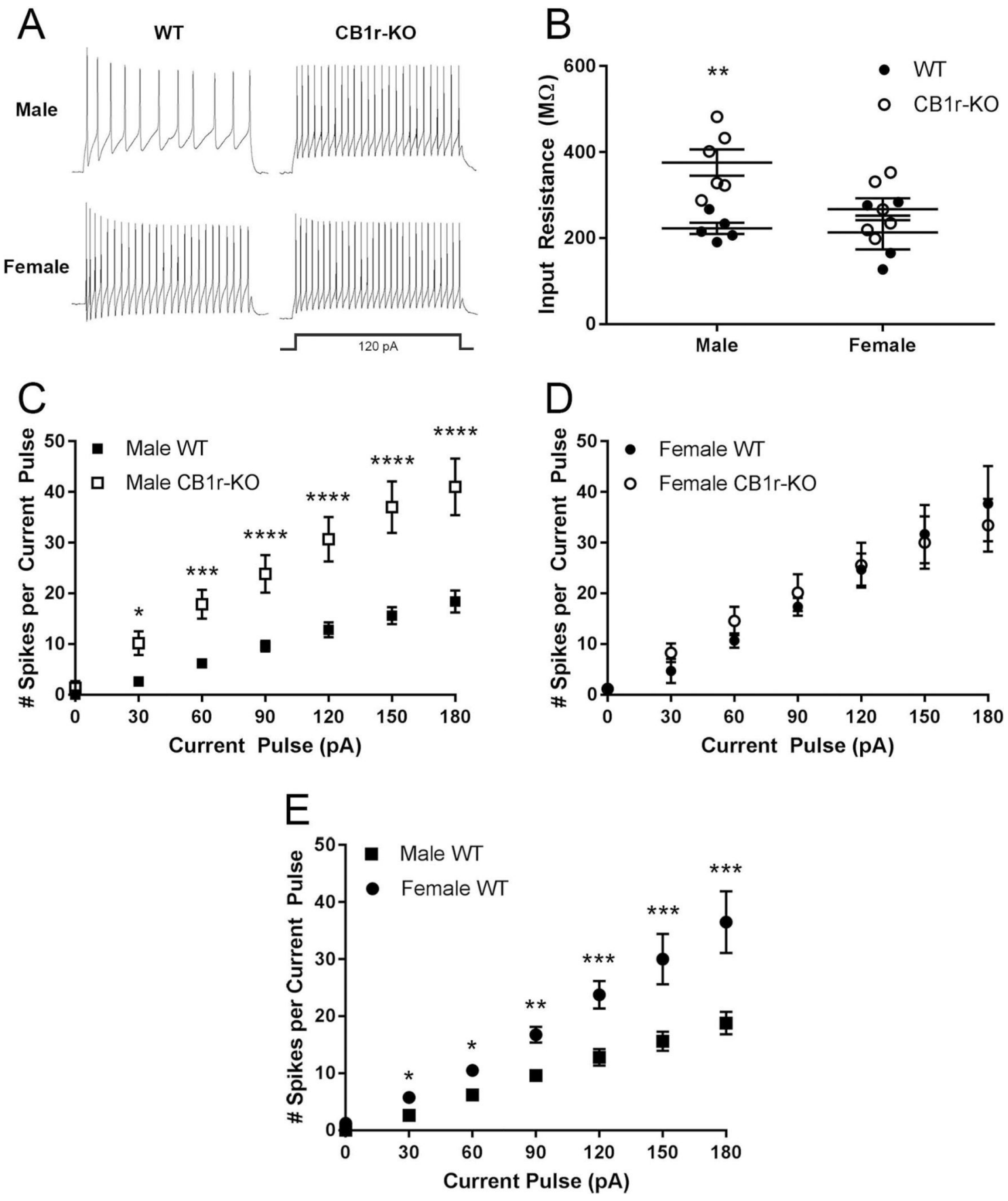

Figure 1: CB1r deletion causes an increase in LC-NE excitability in male mice.

a. Voltage responses to a $120 \mathrm{pA}$ current pulse from representative $\mathrm{WT}$ and CB1r-KO male and female mice. b. LC-NE neurons from male CB1r-KO mice have a significantly larger input resistance compared to WT males $(\mathrm{p}=0.006)$ and WT females $(\mathrm{p}=0.005)$. CB1r deletion does not cause a change in input resistance in female LC-NE cells. Panels $\mathbf{c}, \mathbf{d}$, and e summarize excitability data in the form of stimulus-response curves to a range of current pulses (0-150 pA in $30 \mathrm{pA}$ increments) in male and female WT and CB1r-KO mice. CB1r deletion results in a significant increase in excitability of LC-NE cells in male mice 
(leftward shift in c), which it does not affect LC-NE excitability in female mice (no shift in d). e. Female WT mice have a significant increase in LC-NE excitability compared to male WT mice. $\mathrm{N}=5$ cells from $5 \mathrm{WT}$ males, $\mathrm{N}=4$ cells from $4 \mathrm{WT}$ females, $\mathrm{N}=6$ cells from $5 \mathrm{KO}$ males, $\mathrm{N}=6$ cells from $4 \mathrm{KO}$ females. Data represent mean \pm SEM. Astrisks indicate a significant difference between groups as determined by two-way and three-way repeated measure ANOVAs/mixed-effects regression model $(* \mathrm{p}<0.05 ; * * \mathrm{p}<0.01$, *** $\mathrm{p}<0.001$, $* * * * \mathrm{p}<0.0001)$. 

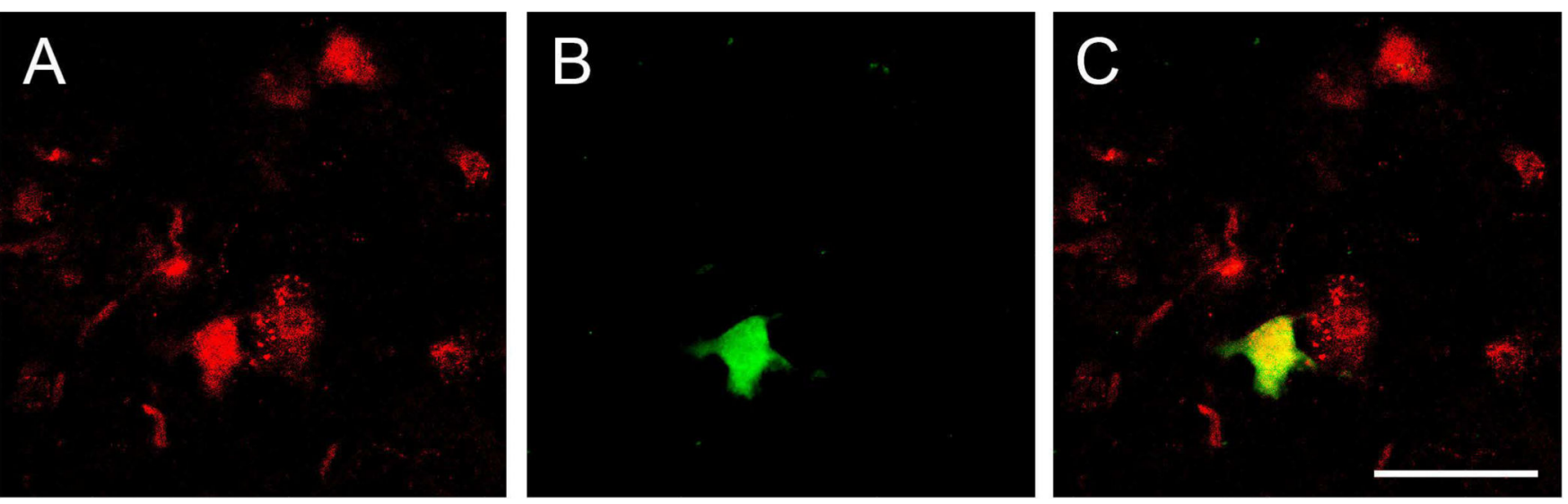

Figure 2: Confirming electrophysiological data is obtained from NE producing cells within the LC.

Confocal fluorescence micrographs showing TH (red), biocytin (green), and co-localization (yellow) in the LC. a. TH was detected using an Alexa Fluor 647-conjugated secondary antibody. b. Biocytin was detected using an Alexa Fluor 488-conjugated streptavidin antibody. c. Arrow depicts co-localization between biocytin and TH, confirming that the patched cell was an LC-NE neuron. Single arrowheads indicate TH labeled cell bodies in the LC that were not patched. Scale bar $=25 \mu \mathrm{m}$. 

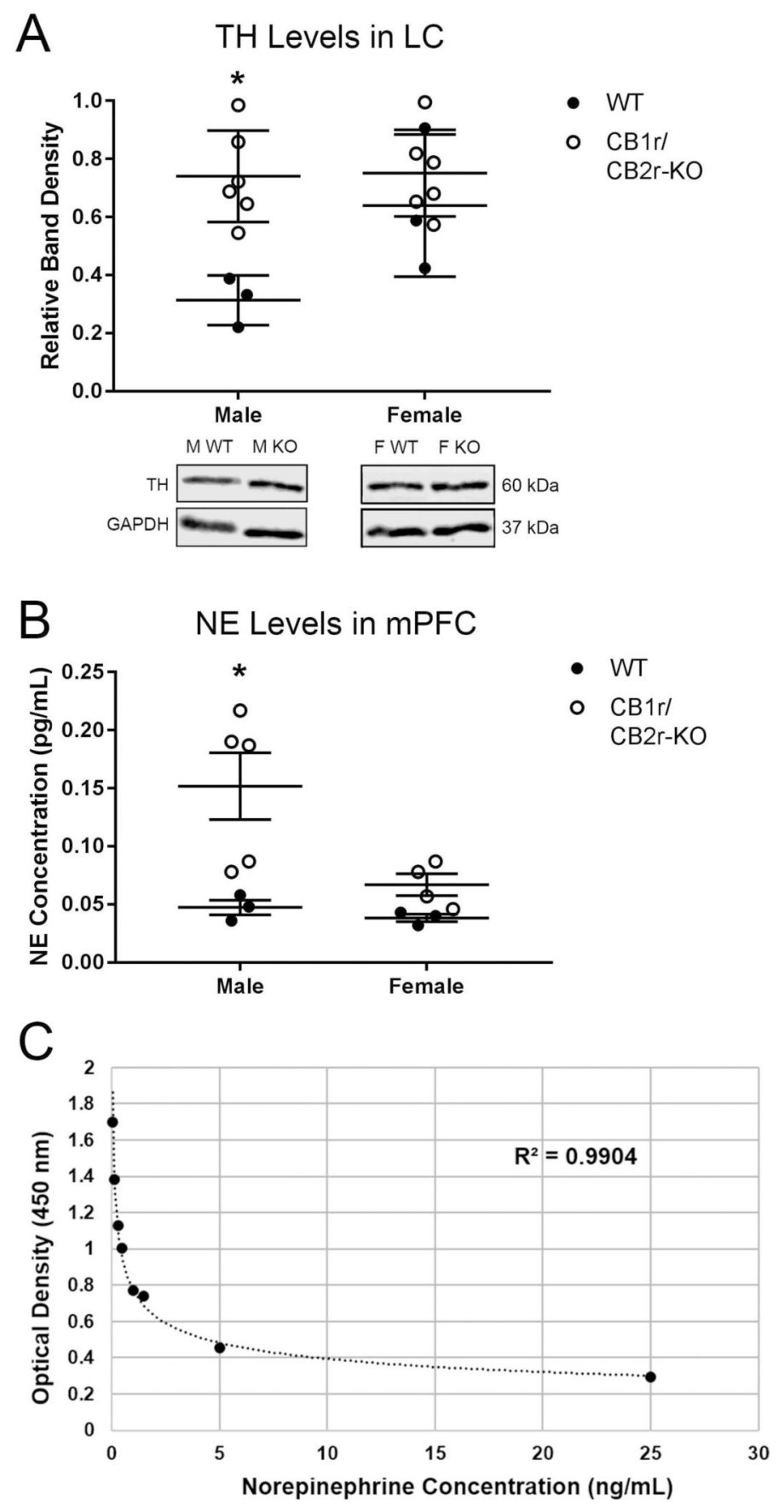

Figure 3: Western blot and ELISA analyses of NE indices in the LC and $\mathrm{mPFC}$ of male and female WT and CB1r/CB2r-KO mice.

Bands shown are representative of one sample obtained from one animal per group. $\mathbf{a}$. Western blot analysis for TH in protein extracts from the LC of male and female WT and $\mathrm{CB} 1 \mathrm{r} / \mathrm{CB} 2 \mathrm{r}-\mathrm{KO}$ mice. TH expression is significantly higher in male CB1r/CB2r-KO mice compared to male WT mice ( $\mathrm{p}=0.005)$; however, there is no significant change in $\mathrm{TH}$ expression between female WT and CB1r/CB2r-KO ( $\mathrm{p}=0.77)$. N=3 WT males, N=6 KO males, $\mathrm{N}=3 \mathrm{WT}$ females, and $\mathrm{N}=6 \mathrm{KO}$ females. b. ELISA for NE in protein extracts from 
the mPFC of male and female WT and CB1r/CB2r-KO mice. NE levels are significantly increased in male CB1r-KO mice compared male WT ( $\mathrm{p}=0.021)$, female WT $(\mathrm{p}=0.012)$, and female $\mathrm{CB} 1 \mathrm{r} / \mathrm{CB} 2 \mathrm{r}-\mathrm{KO}$ mice $(\mathrm{p}=0.041)$. CB1r deletion does not cause an increase in mPFC NE levels in female mice ( $\mathrm{p}=0.79$ ). $\mathrm{N}=3$ WT males, $\mathrm{N}=5 \mathrm{KO}$ males, $\mathrm{N}=3$ WT females, and $\mathrm{N}=4 \mathrm{KO}$ females. . Standard curve used to determine the NE concentration in LC protein extracts from each sample animal. Standards were run on the same plate as samples to avoid variability, and the $\mathrm{R}^{2}$ value for the curve equals 0.9904. Data represent mean $\pm \mathrm{SEM}$. Asterisks indicate a significant difference between groups as determined by two-way ANOVAs/mixed-effects regression model $(* \mathrm{p}<0.05)$. 

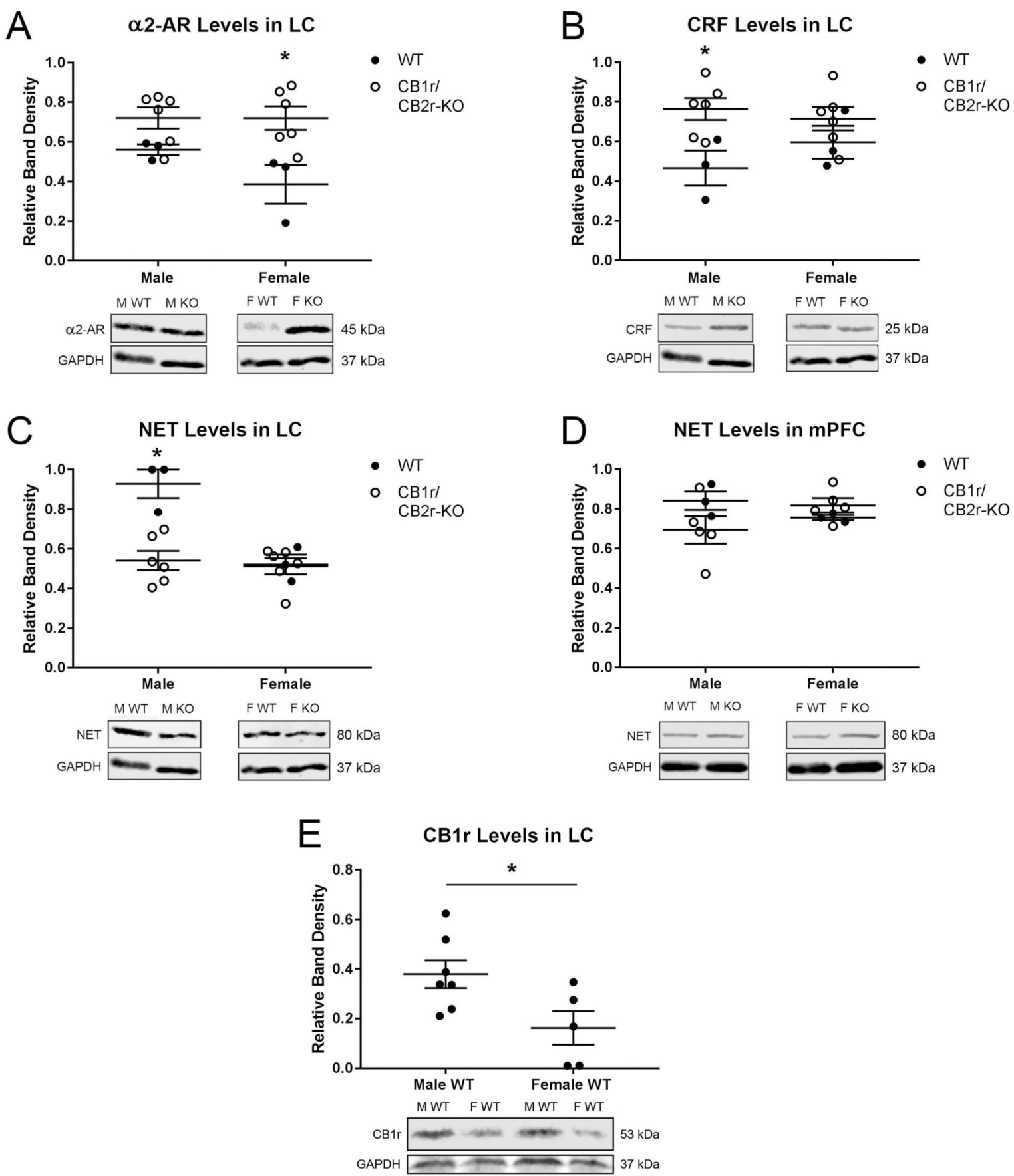

Figure 4: Western blot analysis of a2-adrenoreceptor (a2-AR), corticotropin-releasing factor (CRF), and norepinephrine transporter (NET) expression in the LC and $\mathrm{MPFC}$ in male and female WT and CB1r/CB2r-KO mice.

Bands shown are representative of one sample obtained from one animal per group. LC blots were stripped and reincubated, and multiple proteins were probed on the same blots. a. Western blot analysis for a2-AR expression in protein extracts from the LC of male and female WT and CB1r/CB2r-KO mice. CB1r/CB2r deletion causes a significant increase in a 2-AR expression compared to WT mice in females $(\mathrm{p}=0.016)$, but no change in males $(\mathrm{p}=0.70)$. N=3 WT males, $\mathrm{N}=6 \mathrm{KO}$ males, $\mathrm{N}=3 \mathrm{WT}$ females, and $\mathrm{N}=6 \mathrm{KO}$ females. $\mathbf{b}$. 
Western blot analysis for CRF expression in protein extracts from the LC of male and female WT and CB1r/CB2r-KO mice. There is a significant increase in CRF levels in the LC of male $\mathrm{CB} 1 \mathrm{r} / \mathrm{CB} 2 \mathrm{r}-\mathrm{KO}$ mice compared to male WT mice $(\mathrm{p}=0.045)$, while no change occurs in female mice ( $\mathrm{p}=0.65)$. $\mathrm{N}=3$ WT males, $\mathrm{N}=6 \mathrm{KO}$ males, $\mathrm{N}=3 \mathrm{WT}$ females, and $\mathrm{N}=6 \mathrm{KO}$ females. c. Western blot analysis for NET expression in protein extracts from the LC of male and female WT and CB1r/CB2r-KO mice. Male WT mice have significantly greater NET levels in the LC compared to male CB1r/CB2r-KO ( $\mathrm{p}=0.001)$, female WT $(\mathrm{p}=0.002)$, and female CB1r/CB2r-KO mice ( $\mathrm{p}=0.005$ ). $\mathrm{N}=3$ WT males, $\mathrm{N}=6 \mathrm{KO}$ males, $\mathrm{N}=3 \mathrm{WT}$ females, and $\mathrm{N}=6 \mathrm{KO}$ females. $\boldsymbol{d}$. Western blot analysis for NET expression in protein extracts from the mPFC of male and female WT and CB1r/CB2r-KO mice. No significant change in NET expression is observed across sexes or genotype. $\mathrm{N}=3 \mathrm{WT}$ males, $\mathrm{N}=5 \mathrm{KO}$ males, $\mathrm{N}=3 \mathrm{WT}$ females, and $\mathrm{N}=4 \mathrm{KO}$ females. e. Western blot analysis for $\mathrm{CB} 1 \mathrm{r}$ expression in protein extracts from the LC of male and female WT mice. Male WT mice have significantly greater CB1r expression in the LC compared to female WT mice ( $\mathrm{p}=0.033)$. N=7 WT male mice and $\mathrm{N}=5 \mathrm{WT}$ female. Data represent mean $\pm \mathrm{SEM}$. Asterisks indicate a significant difference between groups as determined by two-way ANOVAs/mixed-effects regression model $(* \mathrm{p}<$ $0.05)$. 

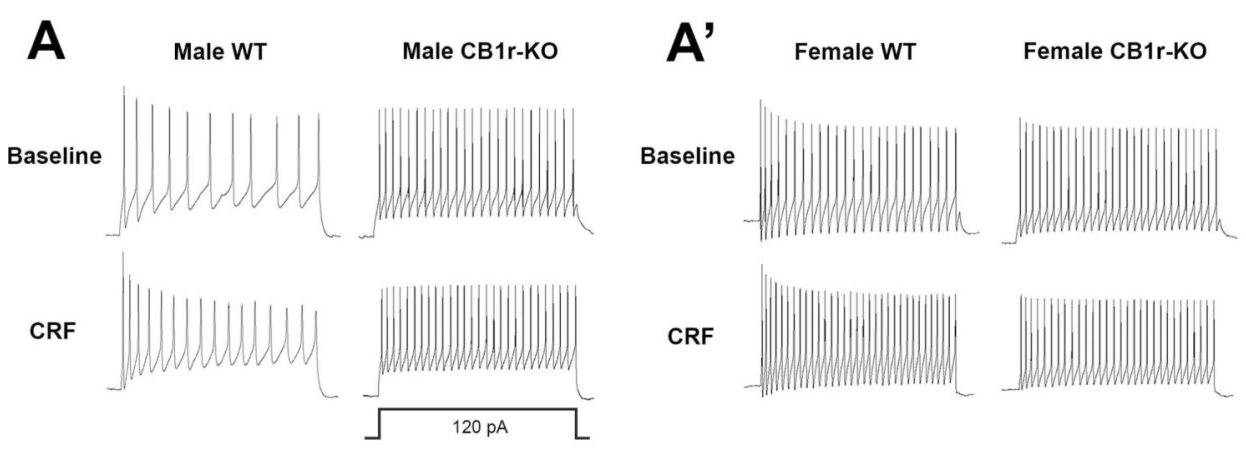

B

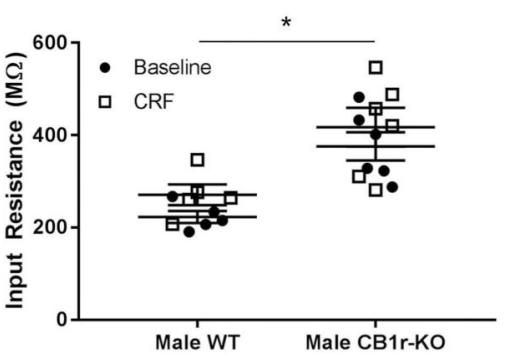

B'
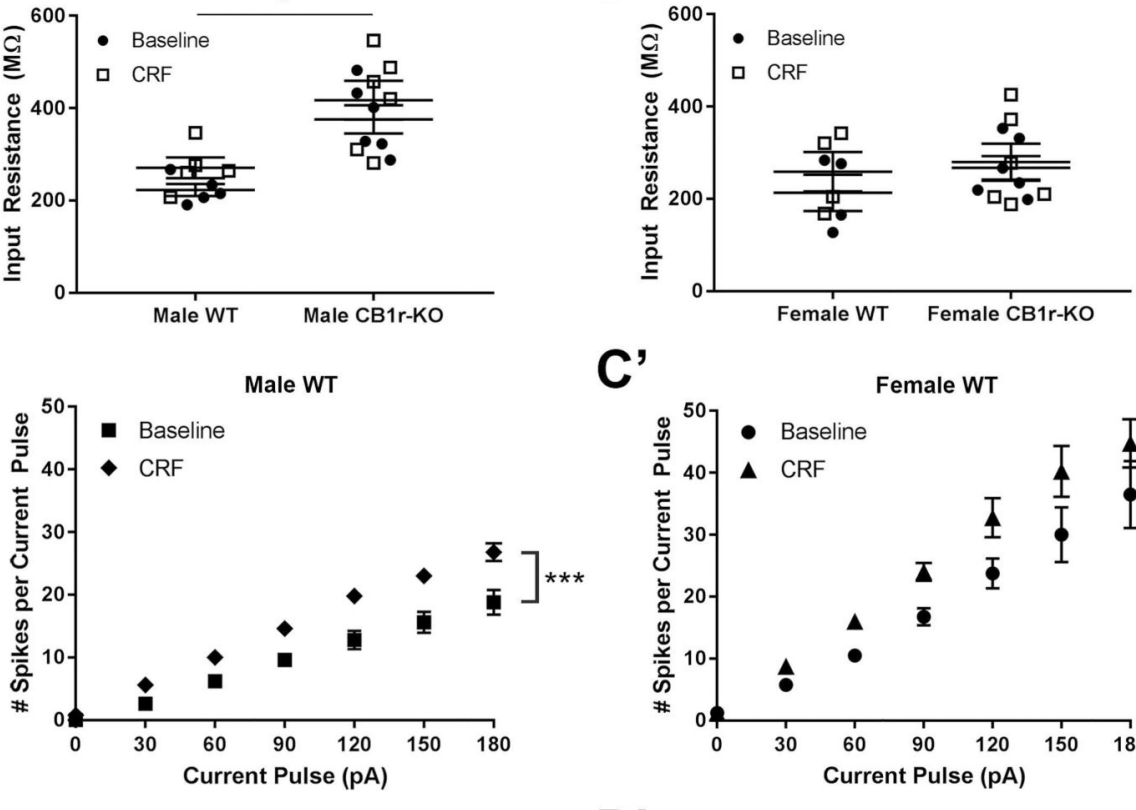

\section{C}

D
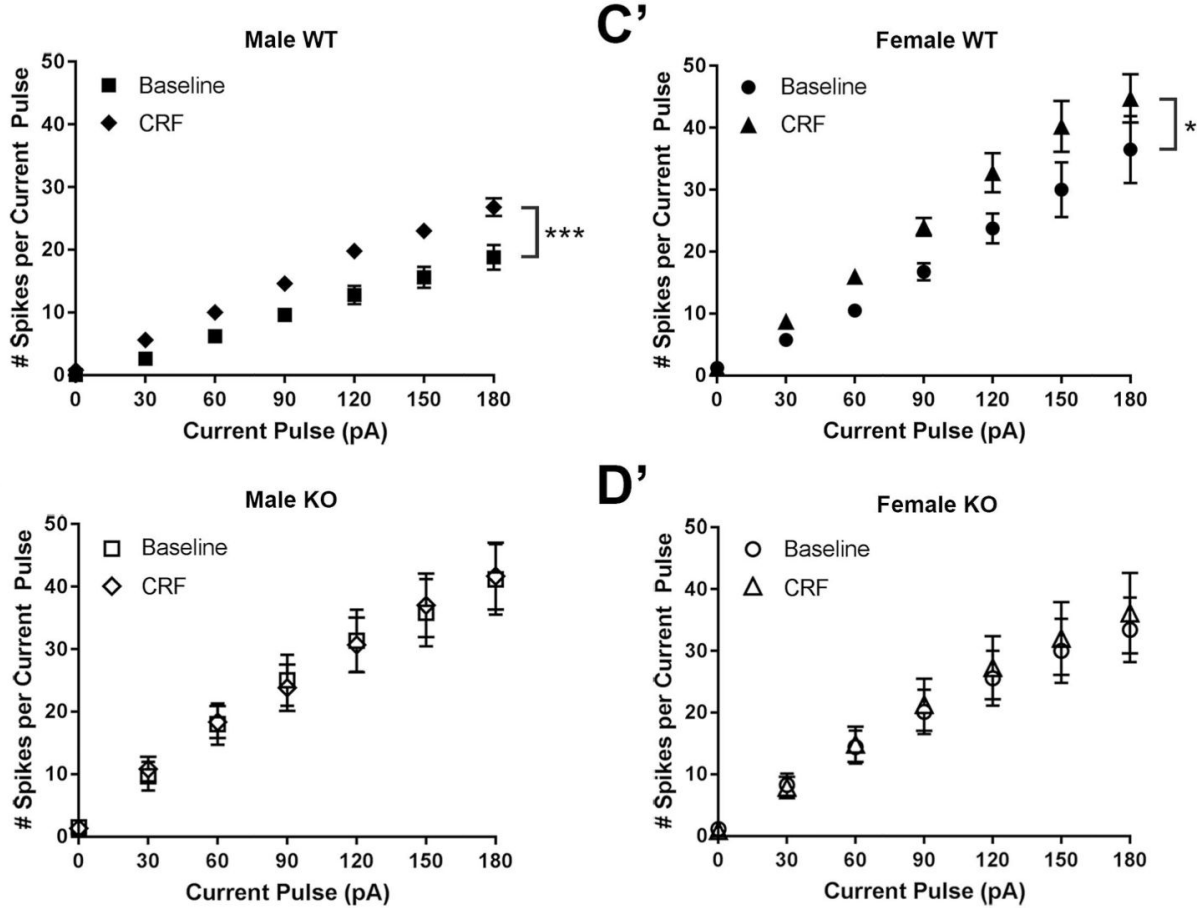

D'

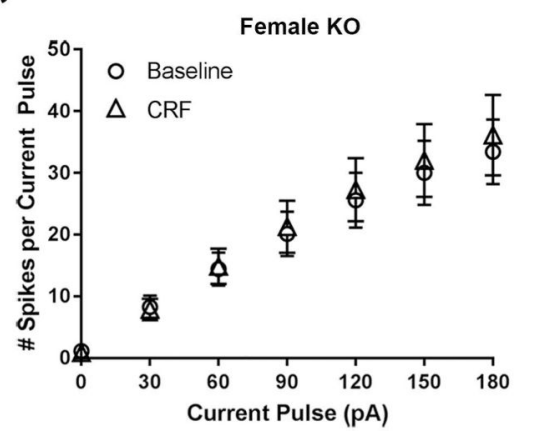

Figure 5: CB1r deletion disrupts CRF-induced increases in LC-NE excitability in male and female mice.

Voltage responses to a $120 \mathrm{pA}$ current pulse are shown from representative WT and CB1rKO male (a) and female (a') mice both at baseline and following CRF (300 nM) treatment. b. Bath application of CRF ( $300 \mathrm{nM})$ does not cause in increase in WT or CB1r-KO neuronal excitability in male or female (b') mice. Panels $\mathbf{c}, \mathbf{c}$ ', $\mathbf{d}$, and d' summarize excitability data in the form of stimulus-response curves to a range of current pulses (0-150 $\mathrm{pA}$ in $30 \mathrm{pA}$ increments). Bath application of CRF $(300 \mathrm{nM})$ results in a significant increase 
in excitability of LC-NE cells in male WT mice (leftward shift in c) and female WT mice (leftward shift in c'); however, $300 \mathrm{nM}$ CRF does not alter the excitability of LC-NE cells in male CB1r-KO mice (no shift in d) and female CB1r-KO mice (no shift in d'). $\mathrm{N}=5$ cells from 5 WT males, $\mathrm{N}=4$ cells from 4 WT females, $\mathrm{N}=6$ cells from $5 \mathrm{KO}$ males, $\mathrm{N}=6$ cells from $4 \mathrm{KO}$ females. Data represent mean \pm SEM. Asterisks indicate a significant difference between groups as determined by two-way ANOVA (c and $\left.\mathbf{c}^{\prime}\right)$ and four-way repeated measure ANOVAs/mixed-effects regression model (d, d', e, and $\mathbf{e}$; * p < 0.05; *** p $<0.001)$. 


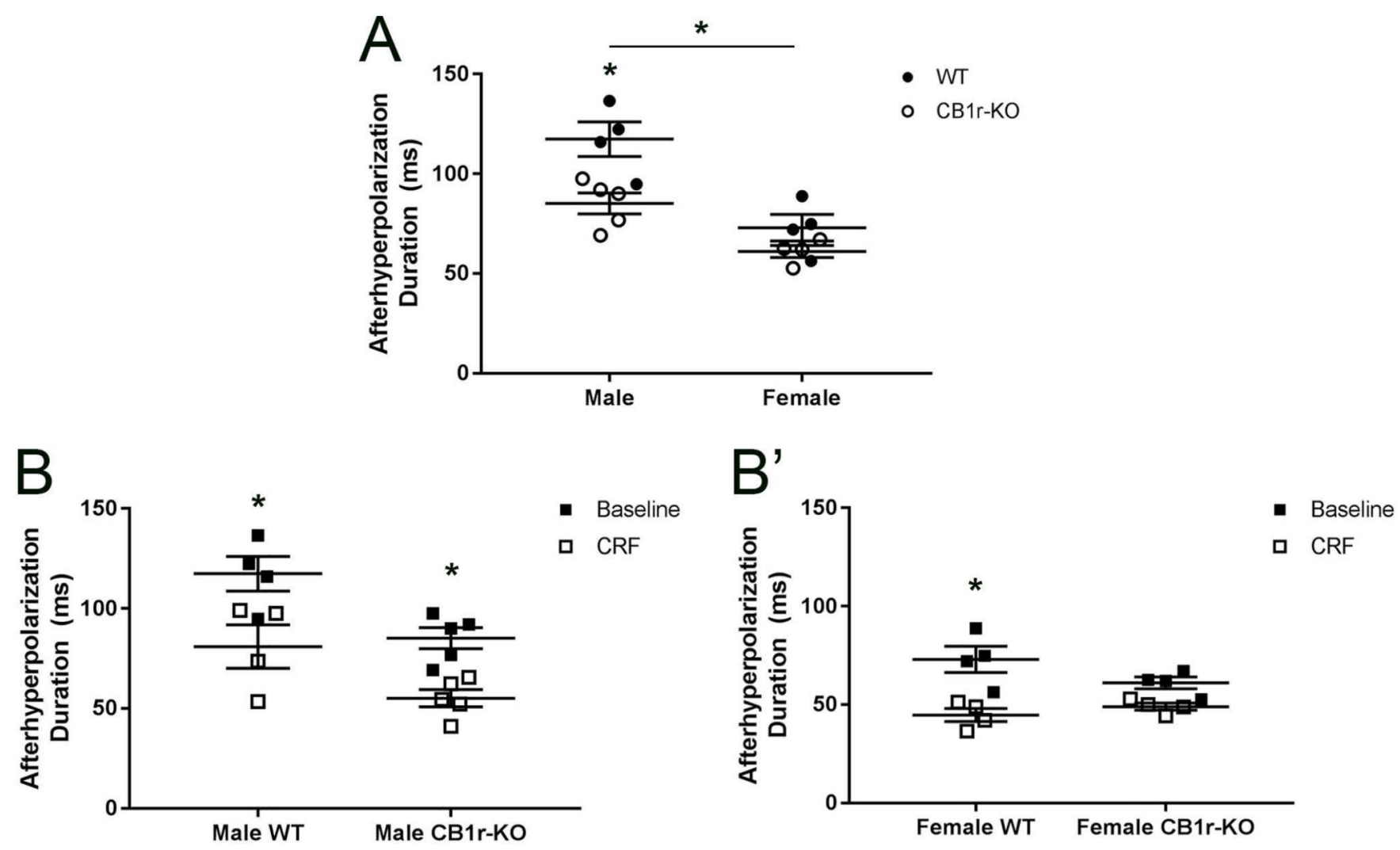

Figure 6: Sex, genotype, and CRF treatment affect the after-hyperpolarization (AHP) duration of LC-NE neurons.

a. LC-NE cells from female WT mice have a significantly shorter AHP duration compared to cells from WT males ( $\mathrm{p}=0.001)$. Additionally, there is a sex difference in the effect of $\mathrm{CB} 1 \mathrm{r}$ deletion, with neurons from male $\mathrm{CB} 1 \mathrm{r}-\mathrm{KO}$ mice having a shorter AHP duration compared to neurons male WT mice ( $\mathrm{p}=0.002$ ), but no difference between female $\mathrm{CB} 1 \mathrm{r}-\mathrm{KO}$ and WT cells ( $\mathrm{p}=0.38$ ). $\mathbf{b}$ and $\mathbf{b}$ ' show the effect of $300 \mathrm{nM}$ CRF bath application on the AHP duration of LC-NE cells, separated by sex. b. CRF causes a significant reduction in AHP duration in both male WT $(\mathrm{p}=0.004)$ and male CB1r-KO neurons $(\mathrm{p}=0.013)$. b'. CRF causes a significant reduction in AHP duration in female WT $(\mathrm{p}=0.002)$ but not female CB1r-KO ( $\mathrm{p}=0.069$ ) neurons. $\mathrm{N}=4$ cells from 4 WT males, $\mathrm{N}=4$ cells from 4 WT females, $\mathrm{N}=5$ cells from $5 \mathrm{KO}$ males, $\mathrm{N}=4$ cells from $4 \mathrm{KO}$ females. Data represent mean $\pm \mathrm{SEM}$. Asterisks indicate a significant difference between groups as determined by two-way ANOVAs/mixed-effects regression model $(* \mathrm{p}<0.05)$. 

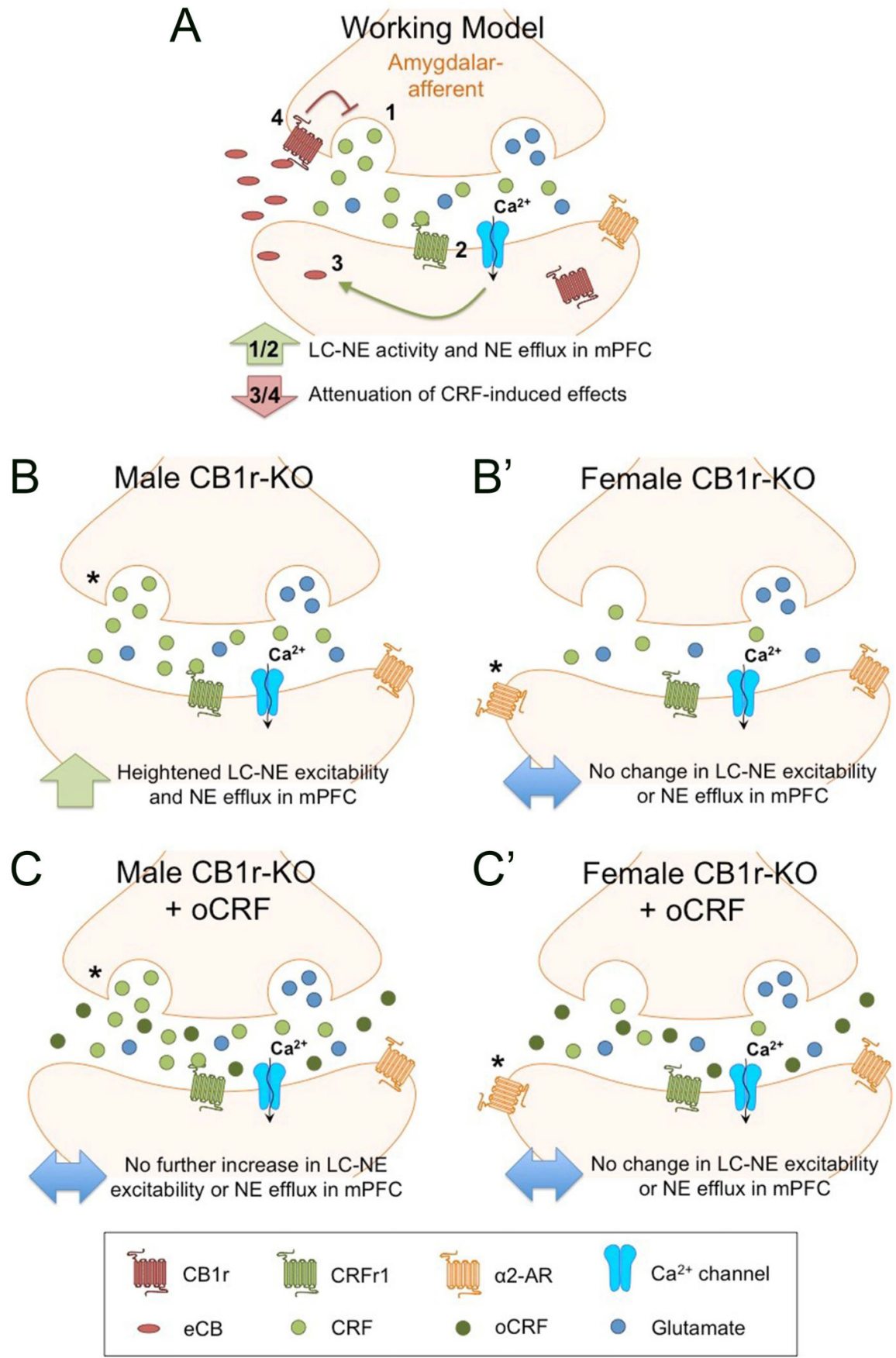

Figure 7: Schematic depicting the effects of CB1r deletion on LC-NE indices.

This schematic is contains a combination of results from electrophysiology studies performed in CB1r-KO mice with Western blot and ELISA analysis performed on CB1r/ CB2r-KO tissue. a. Our working model depicting how the endocannabinoid (eCB) system might modulate CRF-mediated responses within the LC. (1) Stressors cause CRF to be released from excitatory amygdalar afferents into the LC. (2) CRF binds to its postsynaptic CRF type 1 receptor (CRFr1), and subsequent post-synaptic depolarization and $\mathrm{Ca}^{2+}$ influx leads to increased LC-NE excitability and NE efflux in the mPFC. (3) Increased intracellular 
$\mathrm{Ca}^{2+}$ levels stimulate eCB production, which then cross the synapse in a retrograde fashion to bind to their cannabinoid type 1 receptors (CB1r). (4) CB1r activation leads to inhibition of pre-synaptic CRF and glutamate release, attenuating CRF-induced increases in LC-NE excitability and NE efflux in the mPFC. b. Male CB1r/CB2r-KO mice have increased CRF expression within the LC, which could be responsible for the heightened LC-NE excitability and subsequent NE efflux in the mPFC. b'. Female CB1r/CB2r-KO mice do not have a significant increase in CRF levels, which corresponds with the lack of change in LC-NE excitability and NE efflux in the mPFC of CB1r-KO mice compared to wild type mice. However, there is a significant increase in a2-adrenoceptor (a2-AR) expression in female $\mathrm{CB} 1 \mathrm{r} / \mathrm{CB} 2 \mathrm{r}-\mathrm{KO}$ mice compared to WT, while there is no significant change in a2-AR expression in males. c. Bath application of ovine CRF (oCRF) causes a significant increase in male and female WT mice, but not in CB1r-KO mice. In males, this might be due to saturation of CRFr1 by the increased endogenous CRF levels. c'. In females, the lack of oCRF-induced increases in LC-NE excitability could be attributed to the significant increase in a2-AR expression. oCRF could induce local NE release and subsequent auto-inhibition, preventing oCRF-induced increases in LC-NE activity. 
Table I:

Characterization of the primary antibodies used for immunofluorescence microscopy (IF) and Western blotting (WB

\begin{tabular}{|c|c|c|c|c|c|c|}
\hline Antigen & Immunogen & Host & Source & Catalog \# & Dilution & References \\
\hline Biocytin & $\begin{array}{l}\text { A biotin-binding protein } \\
\text { (streptavidin) covalently } \\
\text { attached to a fluorescent label } \\
\text { (Alexafluor 488) }\end{array}$ & $\mathrm{n} / \mathrm{a}$ & ThermoFisher Scientific & S32354 & 1:500 (IF) & $\begin{array}{l}\text { Li \& Kirby } \\
\text { (2016) }\end{array}$ \\
\hline $\mathrm{TH}$ & $\begin{array}{l}\text { TH purified from rat } \mathrm{PC} 12 \\
\text { cells }\end{array}$ & Mouse & Immunostar Inc & 22941 & $\begin{array}{l}1: 1000(\mathrm{IF} \& \\
\mathrm{WB})\end{array}$ & $\begin{array}{l}\text { Van Bockstaele } \\
\& \text { Pickel (1993), } \\
\text { Oropeza et al. } \\
(2005)\end{array}$ \\
\hline a2-AR & $\begin{array}{l}\text { Synthetic peptide, amino acids } \\
218-235 \text { of human, rat, and pig }\end{array}$ & Rabbit & Millipore Sigma & SAB4500548 & 1:500 (WB) & $\begin{array}{l}\text { Reyes et al. } \\
\text { (2009), Reyes et } \\
\text { al. (2017) }\end{array}$ \\
\hline $\mathrm{CRF}$ & Synthetic CRF peptide & Guinea-pig & Peninsula Laboratories & $\mathrm{T}-5007$ & 1:2000 (WB) & $\begin{array}{l}\text { Rudoy et al. } \\
(2009)\end{array}$ \\
\hline NET & $\begin{array}{l}\text { Sodium-dependent NET } \\
\text { recombinant protein epitope } \\
\text { signature tag (PrEST) }\end{array}$ & Mouse & Millipore Sigma & MAB5620 & $1: 1000$ (WB) & $\begin{array}{l}\text { Reyes et al. } \\
(2009)\end{array}$ \\
\hline $\mathrm{CB} 1 \mathrm{r}$ & $\begin{array}{l}\text { Directed towards last } 72 \text { amino } \\
\text { acid residues (401-473) of rat } \\
\text { CB1r }\end{array}$ & Guinea-pig & Gift from Dr. Mackie & $\mathrm{n} / \mathrm{a}$ & 1:500 (WB) & $\begin{array}{l}\text { Reyes et al. } \\
(2015)\end{array}$ \\
\hline GAPDH & $\begin{array}{l}\text { GAPDH fusion protein } \\
\text { Ag0766 }\end{array}$ & Mouse & ProteinTech & 60004-I-Ig & $1: 2000(\mathrm{WB})$ & Ross et al. (2017) \\
\hline
\end{tabular}




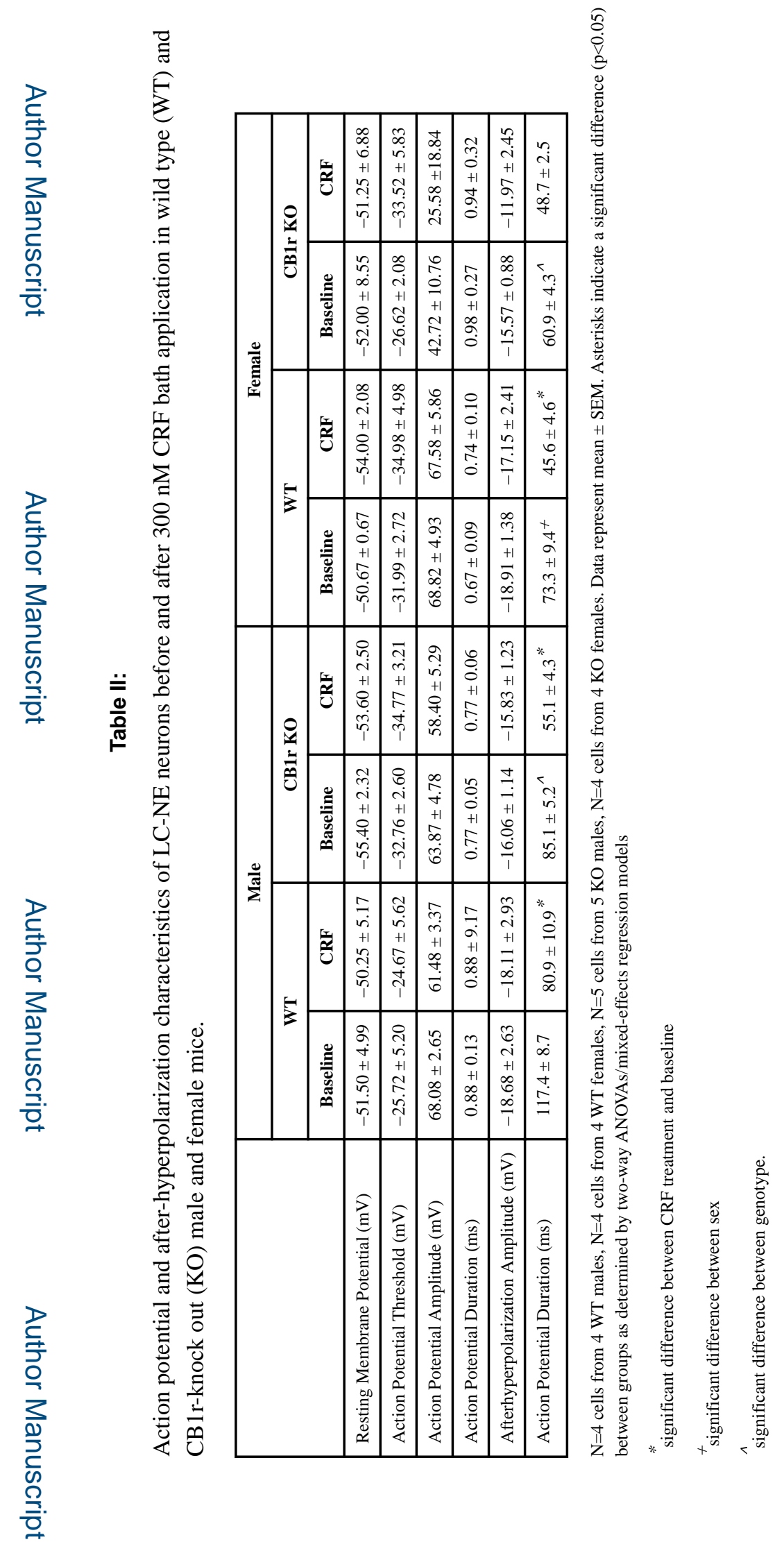

Eur J Neurosci. Author manuscript; available in PMC 2019 September 01. 